\title{
Sustainable Decision Model for Liner Shipping Industry
}

\author{
Calwin S.Parthibaraj* \\ Department of Mechanical Engineering, \\ Dr.Sivanthi Aditanar College of Engineering, \\ Tiruchendur 628 215, India \\ pscalwin@gmail.com
}

\section{Nachiappan Subramanian}

Nottingham University Business School China, 199 Taikang East Road,

Ningbo 315 100, China

nachiappan.subramanian@nottingham.edu.cn +86-574-88180197

Palaniappan PL.K.

Department of Mechanical Engineering, Thiagarajar College of Engineering,

Madurai - 625015, India kpal@tce.edu

\section{Kee-hung Lai}

Department of Logistics and Maritime Studies The Hong Kong Polytechnic University Hung Hom, Kowloon, Hong Kong, mike.lai@polyu.edu.hk

* Corresponding author 


\section{Sustainable Decision Model for Liner Shipping Industry}

Abstract. International trade growth is facilitated by the container liner industry; however, liner shipping companies encounter operational challenges caused by the supply-demand mismatch of ship capacity, and competition between carriers and shippers in negotiating freight rates. Such concerns are resolved in liner shipping conferences; however, the European Commission has banned this practice because of its monopolistic characteristics, thus presenting the need for the liner shipping industry to control capacity and freight rates by adopting an independent information exchange system. Hence, we design a multi agent system technology for the primary and secondary markets, an iterative combinatorial auction mechanism applying Vickrey-Clarke-Groves payments to allocate slots economically efficient at flexible prices, and to maximise the profits of shipping companies considering ship routing and deployment plans. The complete enumerative solution methodology with binary sets and combinations representation with logical search for the multi agent system model was developed using Microsoft Visual $\mathrm{C}++$, and also the mathematical model for the prevailing practices in liner shipping industry was developed and solved using the CPLEX 12.5 solver in AIMMS software. A comparison of the results showed that the Multi agent system is effective in making sustainable decisions by sharing the cost and benefits than prevailing practices in liner industry.

Keywords: Liner ship fleet deployment, liner ship routing, slot pricing, slot allocation, multi agent system (MAS), iterative combinatorial auction (ICA) 


\section{Introduction}

In container shipping, carriers achieve efficiency gains by supplying ships to increase the volume of trade through an appropriate fleet mix and reduced operating costs, whereas shippers and alliance members demand ship slots (capacity) with frequent shipping services between ports at low freight rates(Lun et al., 2010). However, the freight rate determined in liner conferences between shippers and liner shipping companies is considered anticompetitive in Europe, US and Asian countries. Also the decentralized liner shipping market is dynamic due to supply-demand mismatch of ship slots; complex in making socially and economically sustainable decision on alliance formation, resource allocation, cost and benefits sharing, and on improving the service quality of shared slots. This situation requires liner shipping companies to control capacity and freight rate by using an information exchange system (IES), monitored by an independent third party, to compete in the shipping market. Ting and Tzeng(2004) proposed a revenue management system for liner shipping companies, but that system demanded an integrated pricing, a database, and a dynamic slot control with an effective decision support system to improve revenue and manage the trade imbalances in operations. But the development in agent technology, the design of sustainable agent models in international trade, container distribution and inland distribution by SinhaRay et al. (2003), provides scope for generating revenue by implementing a multi-agent system (MAS). Hence the market players such as shipping lines, carriers, and shippers in liner shipping logistics system are designed as agents to react in complex and dynamic maritime environment.

However, the MAS encounters implementation and computational problems in providing effective cooperation and communication, and a mechanism is required to test and implement 
the system in the real world. The design of demand responsive transportation system as a multi-agent system and solving the resource complementariness and substitutability using a combinatorial auction mechanism by Satuni and Babki (2014) provides scope to apply auction mechanism. Harsha et al. (2010) contributed by designing strong activity rules to suppress the strategic behaviour of bidders in designing iterative combinatorial auctions to promote simple, continual, meaningful bidding and thus, price discovery. Andersson et al., (1999) compares the development in recent algorithms on winner determination problem (WDP) and presents the challenges in finding the computationally tractable algorithms to complex real-world instances. Also Mishra (2011) reported that iterative combinatorial auction (ICA) mechanism with Vickrey-Clarke-Groves (VCG) payments has the characteristics of price discovery, computational ease in winner determination, incentive compatibility, and information privacy among bidders. Hence, it is chosen to allocate a bundle of slots to buyers in an economically efficient manner and the complete enumerative logical search algorithm for WDP to implement ICA with VCG is developed using Microsoft Visual $\mathrm{C}++$ to automate MAS for agile decision making in maritime environment.

Thus, the paper design a MAS with an ICA mechanism to allocate resources economically efficient, at prices determined in the primary market between shippers and liner shipping companies, and in secondary market among the liner shipping companies. The major contribution in the enumerative methodology part is the usage of logical search represented in binary form $(0,1)$ of sets and its combinations to determine winners with maximum auction value and non-repetition of set allocation instead of weighted set packing and branch and bound search algorithms. The profit earned by the shipping lines(agents), and the VickreyClarke-Groves(VCG) payments earned by the shippers(agents) through slot allocation, and the ship with its route for one complete port rotation were determined. In practice, exchange 
of slots among alliance members is based on the trust, contract and mutual understanding between the partners; hence the primary markets was mathematically modelled excluding the secondary market and solved using the CPLEX 12.5 solver in AIMMS software to compare with MAS model.

The next section presents a literature review followed by a description and definition of problem in the liner shipping industry. The prevailing and proposed methodologies for solving the slot allocation, capacity management, and route planning problems are then explained and illustrated. Subsequently, the results obtained from the methodologies are discussed, and the conclusion and future research directions are presented in the final section.

\section{Literature review}

The status of research in areas such as fleet deployment planning, scheduling, routing, slot allocation, slot pricing, MAS and auction mechanisms is presented in this section to indicate the need for a suitable collaborative optimisation model to function in the complex and dynamic maritime environment.

The joint routing and fleet deployment problem identified and solved by Alvarez (2009); the relationship between slow steaming and environmental benefits examined by Psaraftis et al. (2010); and the advantages of minimising fuel emissions by applying appropriate vessel scheduling reported by Qi and Song (2012) revealed fleet management problems, with the demand for alternative models and approaches for obtaining economic and environmental benefits. Furthermore, the design of a liner shipping network by considering slot profit, fluctuation in the demand for slots, and freight rates reported by Chen and Zeng (2010); and the liner shipping revenue management system to maximise freight contribution through slot allocation reported by Ting and Tseng (2004) reveals the need for a solution to slot allocation 
and pricing problem. In addition, Kaoy and Yen (1994) proposed an effective allocation of slots at profitable prices through various forms of alliance, and emphasized further studies to understand its effect on competition. Lu et al. (2010a, 2010b) proposed a mathematical model to determine the slot allocation, and slot sharing among alliance members, with a demand in designing a model to assist cooperation and competition between partners. Thus, from the literature on fleet and revenue management, routing, scheduling, slot allocation, and pricing the need for a cooperative system to encourage competition between market players is acquired.

However, the solution to the vessel scheduling and berthing problem in container terminals through the use of the belief, desire, and intention based agent model reported by Lokuge and Alahakoon (2007); and the application of MAS approaches in container terminal planning and management problems reported by Henesey et al. (2003); the state of art illustrated on the application of agent based models as optimisation technique to complex and distributed systems by Barbati et al. (2012) provides scope for developing a cooperative MAS. It also emphasize to focus on the negotiation mechanism, information handling and validation system, for successful MAS implementation. The computational difficulty in multi-agent system due to coalition formation was presented and a parallel algorithm was proposed by Tombus and Bilgic (2004). However the overview of various auctions and their mechanism design along, with computational challenges in solving strategic and implementation complexities reported by Kalagnanam (2004); and the design of iBundle Extend and Adjust, an ascending price combinatorial auction with strategy proof and limited information disclosure from agents, reported by Parkes (2001), the development of different heuristics to solve WDP for multi-agent resource allocation by Kevin (2003), shows the development and suitability of auction mechanisms to MAS. In addition, Mishra (2007) stated that, by 
providing discounts from the competitive price to the ascending price Iterative ICA, VCG payment to bidders can be obtained and the incentive compatible problem among bidders can be solved.. Mishra (2011) also described a particular ICA that implements the VCG mechanism.

Based on the development of auction mechanisms, the option of ICA is found suitable for resolving the computational, implementation, and incentive compatibility problems of agents at auction and successfully implement MAS to liner shipping market. The description of the problem is presented in the subsequent section.

\section{Problem formulation}

This section addresses the objective criterion, liner ship fleet planning scenario, definition of the problem, slot allocation mathematical model, and MAS model along with its assumptions.

\subsection{Objective criterion}

The objective of this study is to simulate the design of a ship fleet deployment plan, and its itinerary to maximise the profit of shipping lines or carrier agents through sustainable slot allocation and pricing in primary and secondary markets. This simulation also avoids the presence of excess capacity due to non cooperative contracts among shippers and shipping lines in trade market. The paper compares two solution methodologies to achieve these objectives: (1) the formulation of a mathematical model to the prevailing practices on slot allocation among shipping agents, with freight rates determined in liner conference and (2) the formation of an MAS model with efficient ICA algorithm to determine the slot allocation in primary and secondary markets among agents, at prices determined in ICA.

\subsection{Liner ship fleet planning environment}


The maritime trade environment on slot allocation and pricing are explained as follows, A set of owned or chartered ships, $S$, are used by shipping companies to transport containers between set of $M$ possible port pairs representing the origin and destination along an assumed cyclic route $R$, and covering set of ports $P$. Let $N$ be the number of ports to be visited along route $R$; thus, the number of trade markets is $M=(N) *(N-1)$. Each trade market includes shippers demanding ship slots from $N_{S}$ number of ships available at each port. The total voyage cost per twenty-foot equivalent unit (TEU) per day, for carrying the containers with distinct voyage times $\left(T_{S, M}\right)$, includes ship operating, ship capital, bunker, container, terminal handling, maintenance and repair, cargo claims, and administration costs. These costs were obtained from the Stopford (1997),Chen and Zeng (2010) and are used for illustration. Figure 1 illustrates a liner service network in an assumed port rotation of Busan-Osaka-KeelungKaohsiung-Busan.Distances and voyage times, at a speed of 19 knots, obtained from http://www1.axsmarine.com.The demand for ship slots is stochastic and, thus, historical demand data were used, as practised by most of the shipping companies. Currently, freight rates $\left(F R_{S, M}\right)$ for each ship slot along the trade lanes are decided in conferences, and variations in bunker costs and frequent announcements of general rate increases (GRI) result in increased fluctuation in freight rates. In addition, liner conferences are typically anticompetitive. Thus, a pricing mechanism is required for determining freight rates and exchange price to allocate and share ship slots efficiently and maximize the profit for the shipping lines.

Insert Figure 1 here 


\subsection{Problem definition}

Determination of an efficient slot allocation $\left(x_{S, M}\right)$ and fleet deployment plan from $N_{S}$ number of ships provided by liner shipping companies along an assumed itinerary covering $\mathrm{N}$ number of ports to satisfy the demand $\left(D_{M}\right)$ at $M$ number of port pairs given: the available controllable capacities of the $\operatorname{ships}\left(C_{S}\right)$, the total voyage cost for each ship $\left(T V C_{S, M}\right)$ that includes the ship operating, ship capital, bunker, container, terminal handling, maintenance and repair, cargo claims and administration costs, and the freight rate $\left(F R_{S, M}\right)$ for each ship and market.

\subsubsection{Mathematical model}

The mathematical model used for solving the slot allocation problem to maximise the profit

$(z)$ of each ship in trade markets, and to plan the deployment of different ship capacity along a cyclic route is as follows:

Maximise

$$
z=\Sigma_{S, M}\left(F R_{S, M}-T V C_{S, M}\right) x_{S, M}
$$

Subject to

$$
\begin{gathered}
\Sigma_{M}\left(x_{S, M}\right) \leq D C_{S} \forall S \\
\Sigma_{S}\left(x_{S, M}\right) \leq D_{M} \forall M \\
x_{S, M} \geq 0 \quad \forall S \text { and } M
\end{gathered}
$$

The available controllable capacity, $C_{S}$ varies as the ship is allocated with slots $\left(x_{S, M}\right)$ and passes through the ports. Therefore, it is represented by $D C_{S}$, the dynamic capacity of each ship at each port and are calculated using the relation

$$
D C_{S}=C_{S}-\delta_{S, M}\left(x_{S, M}\right)
$$


where $\delta_{S, M}=0$ or 1 to indicate the allocation of slots at port.

\subsubsection{Assumptions of the mathematical model}

- The short sea shipping services with equal vessel speed and voyage time, and common ship route definition are considered to initiate the simulation process.

- The terminal handling times of containers for all ships at all port terminals are considered equal.

- Each container is assumed to be completely filled and considered as one TEU.

- Slot purchases, and exchange agreements among shipping lines in secondary markets for transhipment are not considered to ease the complexity handled in mathematical model

- Freight rates are decided only in liner conferences.

\subsubsection{Multi agent system model}

This sustainable decision model supports fleet deployment plan and efficiently allocate slots among the shippers and shipping companies under cooperative pricing and allocation mechanism. The model consists of two markets, primary market and secondary market. In Primary market, the ship slot provider such as liner shipping companies and carriers, and the slot demander that is shippers are designed as agents to interact through IES. And in secondary market, the shipping companies or carriers are treated as agents to trade the slot filled in primary market. This approach is explained as follows,

\subsubsection{MAS model for primary market}

In this market, shippers as agents submit their demand for slot to the IES. These slots are bundled as per the assumptions made in MAS model by the slot providers and presented to IES. The IES collects the bid from the shippers for each bundle and works unbiased by using 
ICA to coordinate the agents in pricing $\left(F R_{S, M}\right)$ and allocation $\left(S L_{S, M}\right)$. The revenue for the liner shipping companies and VCG payments for each shipper are calculated based on the output from the IES. Figure 2 shows the MAS model for agents in primary market.

Insert Figure 2 here

The profit earned by the slot provider in the primary market $\left(\mathrm{PSH}_{S, M}\right)$ is given by

$P S H_{S, M}=\left(\left(S L_{S, M} * F R_{S, M}\right)-\left(S L_{S, M} * T V C_{S, M}\right)\right) * T_{S, M} \forall$ shipping line agents and markets

Similarly, the profit earned by all of the ships available in the market is determined, and the slot provider with maximal profit earned is selected.

\subsubsection{MAS model for secondary market}

The secondary market is designed with shipping lines as agents interacting with IES to sell or purchase slots at an exchange price determined using ICA mechanism. In this market, the shipping line that demand ship slots are treated as buyer and the neighbouring shipping lines that provides it are considered as seller agents This trade situation arises if the slots won by the shipping line is greater than the available dynamic capacity of the ship in the primary market, or the shipping lines are interested to exchange slots won in primary market. Thus, the slots $\left(y_{S, M}\right)$ selected for auctioning based on this situation in the secondary market are bundled as per the assumptions in MAS model, and presented to IES. The IES request the bids from the liner shipping companies (seller) and the exchange price $\left(E P_{S, M}\right)$ for the allocated slots are determined. . Figure 3 shows the MAS model for secondary market. 
Insert Figure 3 here

The profit $\left(P S C_{S, M}\right)$ earned using the MAS model after slot purchase $\left(y_{S, M}\right)$ by the buyer in each secondary market is obtained using the following equation:

$P S C_{S, M}=\left(\left(E P_{S, M} * y_{S, M}\right)-\left(y_{S, M} * T V C_{S, M}\right)\right) * T_{S, M} \forall$ buyer shipping line agent and markets (7) The total profit earned by the buyer in the secondary market considering the profit earned in primary market is given by,

$z=P S H_{S, M}-P S C_{S, M}$

The total slots served by the buyer in the secondary market after deducting the slots won in the primary market is given by,

$x_{S, M}=S L_{S, M}-y_{S, M}$

Similarly, the profit $\left(P S C_{S, M}\right)$ earned using the MAS model after $\operatorname{slots}\left(y_{S, M}\right)$ sold by the sellers in each secondary trade market is given by,

$P S C_{S, M}=\left(\left(y_{S, M} * V C G_{S, M}\right)-\left(T V C_{S, M} * y_{S, M}\right)\right) * T_{S, M} \forall$ seller shipping line agents and markets $(10)$ The total profit $(z)$ earned by the sellers in the secondary market considering the profit earned in primary market is given by,

$z=P S H_{S, M}+P S C_{S, M}$

and the total slots served by the seller shipping line agents considering slots in primary and secondary market is given by, 


$$
x_{S, M}=S L_{S, M}+y_{S, M}
$$

The overall structure of the MAS and its interaction are presented in Figure 4.

Insert Figure 4 here

\subsubsection{Assumptions in the MAS model}

- Slot purchase, slot exchange and transhipment of containers are considered.

- The procedure for bundle formation are assumed as follows

o ' $\mathrm{n}$ ' blocks are assumed and formed from the demand of container ship slots $\left(D_{S, M}\right)$ in primary market, and slots selected for trade $\left(y_{S, M}\right)$ in the secondary market

○ ' $m$ ' identical bundles of size $(n / m)$ are assumed to obtain bid requests for $2^{m}$ bundle sets $(B S)$

\section{Solution methodology}

In this section, the steps followed for ship fleet deployment planning, slot allocation, and pricing by using the two solution methodologies are explained. Figures 5 and 6 present the methodologies using the flowcharts. 


\subsection{Method 1: CPLEX 12.5 solver in AIMMS software}

The steps followed to solve the ship fleet deployment planning, slot allocation, and pricing problems are

Step1: Input the data, such as freight rate, voyage time, total voyage cost per TEU per day, ships and route, capacity, and the ports along the route.

Step2: Calculate the number of trade markets, total voyage cost and determine the position of each ship.

Step3: Determine the ship available capacity in each trade market of the port.

Step4: If the ships are not available at the port because of a draft condition, set the capacity of ships $=0$; otherwise,

Step5: If ships are at the start position in port rotation, set the available capacity of ships = total capacity, and input the demand data for the trade markets at port, then proceed to Step7; otherwise,

Step6: $\quad$ Set the capacity of ships at initial full capacity minus the transit slots allocated at the previous ports for containers to be transported for more than one sailing leg, and input demand data for the trade markets at that port.

Step7: $\quad$ Solve the slot allocation problem by using the CPLEX 12.5 solver in AIMMS software.

Step8: $\quad$ Add the port of visit for the ship to obtain ship route based on slot allocation in Step7.

Step9: $\quad$ Calculate the profit $(z)$ of each ship. 
Step10: If the port is the end port in the ship itinerary, proceed to Step 11; otherwise,move to the next port and return to Step 4.

Step11: Obtain the ship route, slot allocation, and profit at all trade markets and ships.

Insert Figure 5 here

\subsection{Method 2: Iterative Combinatorial Auction}

The steps followed for solving the slot allocation and pricing problem using an ICA are as follows:

Step1: Input the data, such as voyage time, total voyage cost per TEU per day, ships and route, initial ship full capacity, and the ports to be visited along the route.

Step2: Calculate the numbers of trade markets, total voyage cost, and determine the position of each ship.

Step3: $\quad$ Input demand for the trade markets at that port and form a bundle of slots.

Step4: Determine the agents as shipping lines/carriers and shippers available at the trade markets of the port.

Step5: Run slot allocation and pricing function for each trade market to select the shipping line agent(seller) with maximal profit $\left(P S H_{S, M}\right)$ and allocate ship 
$\operatorname{slots}\left(S L_{S, M}\right)$ to the shippers(buyers) in the primary market. The steps followed at auction are as follows:

Step5.1: $\quad$ Collect bids for the bundle sets from buyers by using the IES.

Step5.2: Initiate the ICA algorithm (Appendices A: Iterative Combinatorial Auction (ICA) and Appendices A.1: Winner Determination Problem(WDP) solution procedure)

Step6: If the demand for slots to be provided by the selected seller agent in the primary market is higher than the capacity available at the ship or if shipping line agents are interested in selling or purchasing ship slots, calculate the number of slots to be traded in the secondary market $\left(y_{S, M}\right)$, and proceed to Step7; otherwise, proceed to Step 8.

Step7: $\quad$ Run slot allocation $\left(y_{S, M}\right)$ and pricing function for the secondary trade market to determine the allocation and profit $\left(P S C_{S, M}\right)$ for the buyer shipping line agent and the seller shipping line agents. The steps followed at auction are as follows: Step7.1: $\quad$ Collect bids for the bundle sets from sellers by using the IES. Step7.2: $\quad$ Initiate the ICA algorithm.

Step8: If all trade markets at the port are allocated, proceed to Step9; otherwise, move to the next trade market and return to Step3.

Step9: If all ports on the assumed itinerary are visited and fulfilled, proceed to Step10; otherwise, move to the next port and return to Step3. 
Step10: Obtain the choice of ship, its route, allocation $\left(x_{S, M}\right)$, profit $(z)$, and agent payments at each market.

Insert Figure 6 here

The solution methodologies are illustrated in the next section.

\section{Numerical explanation}

Table 1 presents input data applicable for both methodologies. The assumed cyclic ship route to be served by the ships deployed is shown in Figure 7.

Insert Figure 7 and Table 1 here

\subsection{Method 1: CPLEX 12.5 solver in AIMMS software}

The number of ports to be visited along the considered route was 4 , and thus, the number of trade markets was 12 . The demand data and ship capacity are entered, and the output solutions from the AIMMS software are obtained.

\subsubsection{Ship position - Busan (A)}

At port A, the trade markets were A-B, A-C, and A-D, and the ship capacity was equal to total capacity. The demand for slots was entered, and the outputs obtained from the AIMMS software are shown in Figure8. 
Insert Figure 8 here

\subsubsection{Ship position - Osaka (B)}

The ship reached Osaka, and the trade markets at port B were B-C, B-D, and B-A port pairs. The dynamic capacity was calculated at Port B by deducting the transit slots from the initial full capacity of the ship if the slots were allocated for trade markets A-C and A-D at port A. The demand for slots was entered, and the outputs obtained from the AIMMS software are shown in Figure9.

Insert Figure 9here

\subsubsection{Ship Position - Keelung(C)}

The ship reached Keelung, and the trade markets at port $\mathrm{C}$ were $\mathrm{C}-\mathrm{D}, \mathrm{C}-\mathrm{A}$, and $\mathrm{C}-\mathrm{B}$. The dynamic capacity was calculated at Port $\mathrm{C}$ by deducting the transit slots from the initial full capacity of the ship if the slots were allocated for trade markets A-D at port A, and B-D, B-A at port B. The demand for slots was entered, and the outputs obtained from the AIMMS software are shown in Figure10.

Insert Figure 10here 


\subsubsection{Ship position - Kaohsiung (D)}

The ship reached Kaohsiung, and the trade markets at port D were D-A, D-B, and D-C. The dynamic capacity was calculated at Port D by deducting the transit slots from the initial full capacity of the ship if the slots were allocated for trade markets B-A at port B, and C-A, C-B at port $\mathrm{C}$. The demand for slots was entered, and the outputs obtained from the AIMMS software are shown in Figure11.

Insert Figure 11here

\subsection{Method 2: Iterative Combinatorial Auction}

The slot allocation and pricing in the primary and secondary markets to maximise the profit for each ship on the considered route are presented in this section. The demand for slots by the shippers (buyers) was bundled in the primary market by the shipping line agents, and the bids were requested for each bundled sets through IES, as shown in Tables2 and 3.

Insert Tables $2 \& 3$ here

\subsubsection{Ship position -Keelung (C)}

For illustration, the ships were considered to be positioned at $\operatorname{Keelung}(\mathrm{C})$, and the trade market C-A was used to explain the proposed methodology. 


\subsubsection{Primary market $C-A$}

The demand for slots for the sailing leg C-A was bundled for auction to the shippers by all the shipping lines available at Port C. The profit earned by the shipping line agents $\left(P S H_{S, M}\right)$ and VCG payment received by shippers in the primary market for the slot allocation $\left(S L_{S, M}\right)$ were calculated, and the results are presented in Table4.

Insert Table 4 here

The shipping line agent with maximal profit was considered as the winner in the primary market, and the available number of slots to be provided by the ship was checked. If the available number of slots was less than the slots demanded by the shippers or if the shipping line agent was willing to trade the slots, the secondary market was initiated. In this illustration, the winner was Ship4, and the secondary market was initiated as the available number of ship slots were less than the slots demanded by the shippers

\subsubsection{Secondary market at $C$ - $A$}

The slots $\left(y_{S, M}\right)$ decided by the shipping line agent won in the primary market were bundled and the bids were requested through IES from the neighbouring shipping line agents in secondary market. The profit earned by the shipping line agent (buyer) in the secondary market $\left(P S C_{S, M}\right)$, slot allocation $\left(\left(y_{S, M}\right), \mathrm{VCG}\right.$ payment for seller shipping line agents, and total profit $(z)$ earned by the buyer and seller shipping line agents were calculated, and the results are presented in Table5. 
Insert Table 5 here

Figure 12 shows a screenshot of the software output obtained using the ICA for Ship 4 in the primary trade market C-A. Similarly, the experiment was performed for all the ports and their trade markets to satisfy the demand along the trade route.

Insert Figure 12 here

\section{Results and comparison}

The results obtained using the two solution procedures are presented and compared in this section.

\subsection{Method 1: CPLEX 12.5 solver in AIMMS software}

The overall profit earned by the ships at each trade market based on the allocation of slots by using the CPLEX 12.5 solver in AIMMS are presented in Table6.

Insert Table 6 here 
Based on the slot allocation, the ship size and their route were determined to transport containers at a low cost between port pairs. The route determined for each ship is shown in Table7.

Insert Table 7 here

\subsection{Method 2: Iterative Combinatorial Auction}

The proposed methodology to achieve cooperation among shippers, and alliance members in determining the slot price $\left(F R_{S, M}\right)$ and exchange price $\left(E P_{S, M}\right)$ was solved, and the results are presented in Tables 8 to 11 for comparison.

\subsubsection{Primary trade market}

Table 8 presents the outputs obtained in the primary markets.

Insert Table 8 here

\subsubsection{Secondary market}

Table 9 presents the outputs obtained in secondary markets along with the exchange price.

Insert Table 9here 
The total profit earned at each port pair $(z)$ and the total slots served by each ship are presented in Table10.

Insert Table 10 here

Based on the slot allocation, the ships of each shipping line and their route were determined to transport containers at a low cost between port pairs considering the shippers involvement in pricing of slots, and cooperation among market players. Table 11 presents the route determined for each ship.

Insert Table 11 here

The results revealed that the ICA consider the social interest of market players to determine the slot allocation among agents at maximal profit in complex, dynamic, and competitive environment when compared with the mathematical models adopted by shipping companies. However, the losses incurred depend on the decision of the shipping line agent to initiate the secondary market as well as the bid values submitted for each trade markets. Also the proposed ICA mechanism requires $\left[\left(2^{(B S-1) * N B}\right) *(M)\right.$, where $\left.B S=2^{N}\right]$, number of iterations to solve the allocation and pricing problem. As complete logical search enumeration of WDP in ICA was done, the computational time was reasonably more, and it depends on the skill, bid distribution and learning ability of the bidders in auction. 


\section{Conclusion and future research}

This study investigated the ship deployment and route planning problem to maximise profit earned by shipping line agents, and to match the demand and supply for ship slots. In this study, the slot allocation and the pricing problem in the liner shipping industry was solved using ICA among agents, and the slots were allocated to shippers and alliance members by exchanging information using an unbiased IES. The MAS with ICA solution methodology was compared with the mathematical model of the prevailing practices of liner shipping industry solved using the CPLEX 12.5 solver in AIMMS software. The results obtained from the MAS model with ICA solution method shows increased profit for shipping companies, flexible freight rates along various ship routes, more involvement of shippers, and improved service quality for the shared slots between the shipping companies. This study also contributes by coupling MAS with an ICA mechanism to involve more market players, and enhance the competitiveness with sustainable resource allocation and alliance formation. Also, the freight rate determined in ICA with VCG payment provides economically efficient allocation with social benefits to the bidders in the dynamic and uncertain liner shipping trade market. Although the relevant information and data for the simulation were obtained from the previous studies, the proposed MAS with ICA methodology must be validated before implementation. In addition, the requirements for a suitable method for bundling ship slots, an algorithm to reduce computational time for solving winner determination problem in ICA, and a method for training agents to value the non homogeneous and complement bundles provide scope for future research. 


\section{References}

Alvarez, J.F. (2009). Joint routing and deployment of a fleet of container vessels. Maritime Economics and Logistics, 2,186-208.

Andersson,A., Tenhunen,M. and Ygge,F. (1999). Integer Programming for Combinatorial Auction Winner Determination, Proceedings of the fourth International Conference on MultiAgent Systems, IEEE,Sweden.

Barbati,M., Bruno,G., \& Genovese,A. (2012). Applications of agent-based models for optimization problems: A literature review. Expert Systems with Applications, 39(5), 60206028.

Chen,C., and Zeng,Q. (2010). Designing container shipping network under changing demand and freight rates. Transport, 25, 46-57.

Debasis, M., and Parkes,D.C. (2007). Ascending price Vickrey auctions for general valuations. Journal of Economic Theory, 132(1), 335-366.

Harsha,P., Barnhart,C., Parkes,C.D., and Zhang,H. (2010). Strong activity rules for iterative combinatorial auction. Computers \& Operations Research,37(7), 1271-1284.

Henesey,L., Wernstedt,F., and Davidsson,F. (2003). Market-Driven Control in Container Terminal Management. Proceedings of the 2nd International Conference on Computer Applications and Information Technology in the Maritime Industries (COMPIT'03); Hamburg, Germany.

Kalagnanam, J., and Parkes, D.C. (2004). Auctions, bidding and exchange design. In D. Simchi-Levi, S.D. Wu. and Z. Shen (eds.), Handbook of Quantitative Supply Chain Analysis: Modeling in the E-Business Era (pp. 143-212). Boston: Kluver.

Kevin, L-H. (2003). Resource allocation in competitive multiagent systems, Ph.d Thesis, Stanford University, USA.

Lokuge,P., and Alahakoon,D. (2007). Improving the adaptability in automated vessel scheduling in container ports using intelligent software agents. European Journal of Operational Research, 177, 1985-2015.

Lu, H-A., Chua., C-W., and Cheb, P-Y.(2010a). Slot Allocation Planning for an Alliance Service with Ship Fleet Sharing. Asia Pacific Management Review, 15(3), 325-339. 
Lu, H-A., Chen, S-L., and Lai, P. (2010b). Slot exchange and purchase planning of short sea services for liner carriers. Journal of Marine Science and Technology, 18(5), 709-718.

Lun, Y.H.V., Lai, K.H., and Cheng, T.C.E. (2010). Shipping and Logistics Management, London: Springer.

Mishra, D. (2011). Efficient Iterative Combinatorial Auctions. USA: Wiley Encyclopedia of Operations Research and Management Science.

Parkes, D.C. (2001). Iterative combinatorial auctions: Achieving economic and computational efficiency. Ph.d Thesis, University of Pennsylvania, USA.

Psaraftis, H-N., and Kontovas, C.A. (2010). Balancing the economic and environmental performance of maritime transportation. Transportation Research Part D: Transport and Environment, 15(8), 458-462.

Qi, X., and Song, D-P. (2012). Minimizing fuel emissions by optimizing vessel schedules in liner shipping with uncertain port times.Transportation Research Part E: Logistics and Transportation Review, 48(4), 863-880.

Rebollo,M., Julian,V., Carrascosa,C., and Botti,V. (2001). A MAS Approach for Port Container Terminal Management. Proceedings of the Third Iberoamerican workshop on DAI-MAS,Spain, pp.1-12.

Satunin,S., \& Babkin,E. (2014). A multi-agent approach to Intelligent Transportation Systems modeling with combinatorial auctions. Expert Systems with Applications, 41(15), 66226633.

Sinha-Ray,P., Carter,J., Field,T., Marshall,J., Polak,J., Schumacher,K., Song,D., Woods.,J. and Zhang,J. (2003). Container World: Global agent-based modelling of the container transport business. Proceedings of the 4th Workshop on Agent-Based Simulation; 2003, Europe.

Stopford, M.(1997). Maritime Economics, London: Routledge.

Ting, S.C. and Tzeng, G.H. (2004). An optimal containership slot allocation for liner shipping revenue management. Maritime Policy and Management, 31(3), 199-211.

Tombus,O., and Bilgic,T. (2004). A column generation approach to the coalition formulation problem in multi-agent systems. Computer \& Operations Research, 31(10), 1635-1653.

Yen, K.P.(1994) Strategic alliances in the liner shipping industry. MScThesis, Massachusetts institute of technology, USA. 


\section{Appendix A: Iterative Combinatorial Auction (ICA)}

The ICA algorithm is explained as follows

Step1: $\quad$ The buyers $\left(\mathrm{N}_{\mathrm{B}}\right)$ are allowed to bid $\left(\mathrm{BV}_{(\mathrm{NB}, \mathrm{BS})}\right)$ bundled sets of the seller

Step2: $\quad$ Iteration count in auction is set from 0 to large value

Step3: If Iteration value is zero, set auction value for all buyers and bundle sets $\left(A V_{(N B, B S)}\right)$ as zero, run WDP including all buyers using their bid value in Step1 and determine an initial allocation $\left(\mathrm{AL}_{(\mathrm{NB}, \mathrm{BS})}\right)$

Step4: $\quad$ Update the array of buyers (bidders) with one if allocated and zero if the buyers are not allocated

Step5: The auction values are incremented for each buyer without allocation in the previous iteration if

Step5.1: The bid value is not equal to zero and

Step5.2: The bundle set having maximum bid value for each buyer and

Step5.3: The auction value of the bundle set with maximum bid value is equal to bid value of any other bundled set of same buyer and

Step5.4: The auction value is less than bid value for the corresponding bid set

Step6: $\quad$ Run WDP with all buyers and excluding one buyer for $\left(\mathrm{N}_{\mathrm{B}}+1\right)$ times and calculate the revenue of seller in $\left(\mathrm{N}_{\mathrm{B}}+1\right)$ markets by adding the auction values for the allocated bundle sets and go to step4, else

Step7: If auction value is equal to bid value for any buyer and for any bundle sets, Run WDP with all buyers and exclude one buyer for $\left(\mathrm{N}_{\mathrm{B}}+1\right)$ times and calculate 
the revenue of seller $\left(\mathrm{N}_{\mathrm{B}}+1\right)$ markets by adding the auction values for the allocated bundle sets

Step8: $\quad$ Store the allocation as final allocation $\left(\mathrm{AL}_{(\mathrm{NB}, \mathrm{BS})}\right)$ of bundle sets to the buyers

Step 9: $\quad$ Calculate the maximum auction value (Competitive Equilibrium price) considering all buyers in the market and store the bundle set and buyer containing the maximum auction value

Step10: $\quad$ Increment the auction value if

Step10.1: The buyer is not the buyer containing maximum auction value

Step10.2: The maximum bid value for the buyer for the bundle sets is greater than the maximum auction value from step9

Step10.3: Run WDP with all buyers and by excluding one buyer for $\left(\mathrm{N}_{\mathrm{B}}+1\right)$ times

Step11: Calculate the seller revenue for the final allocation as in step8 using the auction value in step10 for $\left(\mathrm{N}_{\mathrm{B}}+1\right)$ markets

Step12: $\quad$ else if

Step12.1: The buyer is not the buyer with maximum auction value found in step9 and

Step12.2: The auction value of any other buyer is equal to maximum auction value as in step9

Step13: $\quad$ Run WDP with all buyers and exclude one buyer for $\left(\mathrm{N}_{\mathrm{B}}+1\right)$ times 
Step14: Calculate the seller revenue for the final allocation in step8 using the auction value in step12 for $\left(\mathrm{N}_{\mathrm{B}}+1\right)$ market and the Universal Competitive Equilibrium (UCE) price is reached, stop iteration

Step15: $\quad$ Calculate buyer's VCG payment using the equation Buyer's VCG Payment $=\{($ Sum of auction value of allocated set of slots to the buyer $)-\left[\left(\right.\right.$ Seller revenue in market of all buyers $\left.\left(n_{\left(w_{\mathrm{g}}\right)}^{\mathrm{sA}}\right)\right)-($ Seller revenue in

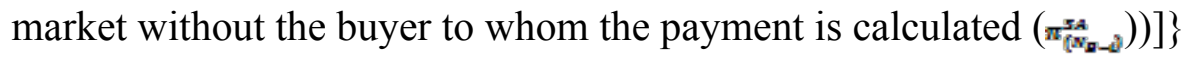

Step16: Output the final allocation, seller revenue in all markets, VCG payments of all buyers

\section{A.1. Winner Determination Problem(WDP) solution procedure}

The algorithm to solve WDP by the seller is given below

Step1: $\quad$ Input number of bundles $(\mathrm{m})$, number of buyers $\left(\mathrm{N}_{\mathrm{B}}\right)$

Step2: $\quad$ Calculate the $\mathrm{BS}=2^{\mathrm{m}}$ number of combinations, with each combination that contains the set of bundles

Step3: Obtain auction value for all the bundle sets in which the buyers are interested

Step4: $\quad$ Calculate the summation of auction value for $2^{(\mathrm{BS})^{*}(\mathrm{NB})}$ allocations checking for the non-repetition of bundles and sets.

Step5: $\quad$ Count the number of winners in each allocation

Step6: Choose the allocation with maximum summation of auction value and more number of winners 


\section{Annexure 1: List of Notation}

\section{Symbol Description}

S Set containing different types of ship

$\mathrm{C}_{\mathrm{S}} \quad$ Ship capacity

R Ship itinerary

P List of ports on assumed ship route (R).

O Port of origin in each trade market

D Port of destination in each trade market

M Set of trade markets

$\mathrm{T}_{\mathrm{S}, \mathrm{M}} \quad$ Voyage Time between each O-D

$\mathrm{TVC}_{\mathrm{S}, \mathrm{M}}$ Total Voyage Cost per TEU per day for each ship and market

$\mathrm{N} \quad$ Number of ports

$\mathrm{N}_{\mathrm{S}} \quad$ Number of ships

$\mathrm{D}_{\mathrm{M}} \quad$ Demand data of slots at each trade market

$\mathrm{FR}_{\mathrm{S}, \mathrm{M}} \quad$ Freight rate per TEU per day for trade market

$\delta_{\mathrm{S}, \mathrm{M}} \quad 0$ or 1 , indicates the transit slots

$\mathrm{X}_{\mathrm{S}, \mathrm{M}} \quad$ slot allocation for distribution/shipment by each ship at markets

$\mathrm{EP}_{\mathrm{S}, \mathrm{M}} \quad$ Exchange price in slot exchange market

$\mathrm{PSH}_{\mathrm{S}, \mathrm{M}} \quad$ The profit earned by ship in shipper's trade market for MAS model

z The total profit earned using mathematical and MAS model by ships 


\begin{tabular}{|c|c|}
\hline $\mathrm{n}$ & Number of blocks with each block size as $D_{M} / n$ \\
\hline $\mathrm{m}$ & Number of bundles with bundle size $(\mathrm{n} / \mathrm{m})$ \\
\hline $\mathrm{BS}$ & Number of bundled sets \\
\hline $\mathrm{N}_{\mathrm{B}}$ & Number of buyers \\
\hline $\mathrm{N}_{\mathrm{B}-\mathrm{i}}$ & Group of buyers excluding $\mathrm{i}^{\text {th }}$ buyer \\
\hline $\mathrm{BV}_{(\mathrm{NB}, \mathrm{BS})}$ & Bid value by buyers for bundled sets \\
\hline $\mathrm{AV}_{(\mathrm{NB}, \mathrm{BS})}$ & Auction value by buyers for sets \\
\hline $\mathrm{SL}_{\mathrm{S}, \mathrm{M}}$ & Slot allocation to shippers in primary market \\
\hline $\mathrm{y}_{\mathrm{S}, \mathrm{M}}$ & Slots for auction in secondary market \\
\hline$n_{\left(N_{a}\right)}^{x a n}$ & Seller revenue in market including all buyers that is main economy \\
\hline$n_{\left(w_{g}-d\right)}^{s A}$ & $\begin{array}{l}\text { Seller revenue in market without the buyer } i \text { to whom the payment is calculated } \\
\text { (Marginal economy) }\end{array}$ \\
\hline $\mathrm{AL}_{(\mathrm{NB}, \mathrm{BS})}$ & Buyers allocation in ICA \\
\hline $\mathrm{PSC}_{\mathrm{S}, \mathrm{M}}$ & Profit earned by the buyer and seller agents in secondary market \\
\hline
\end{tabular}




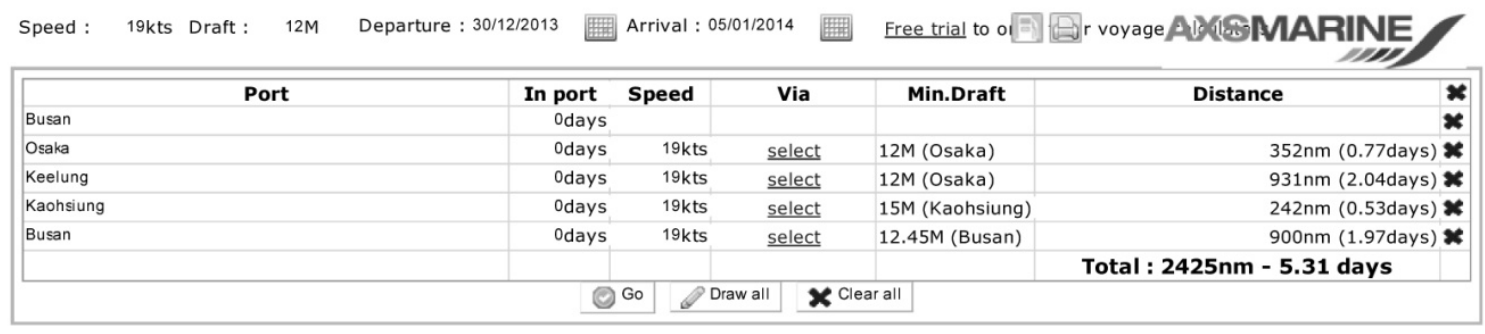

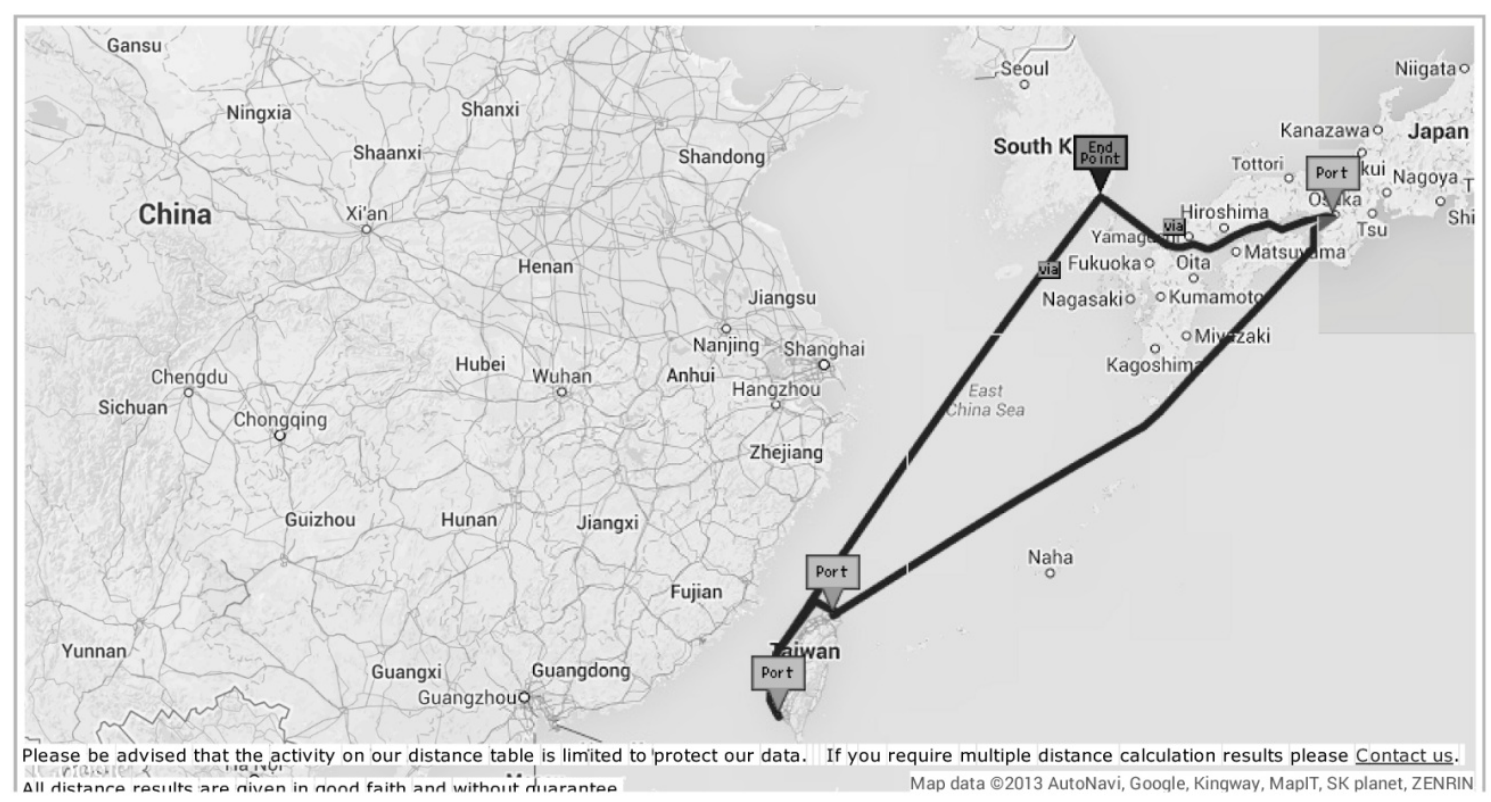

Fig. 1. Liner ship service network assumed in numerical illustration for all liners.

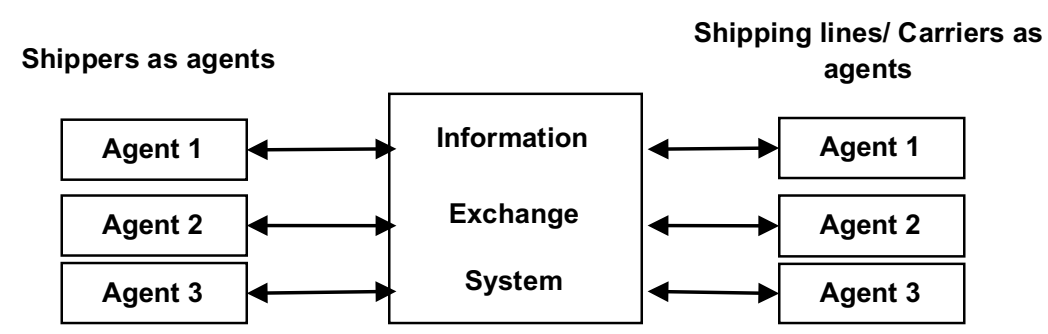

Fig. 2. MAS Model for primary market. 


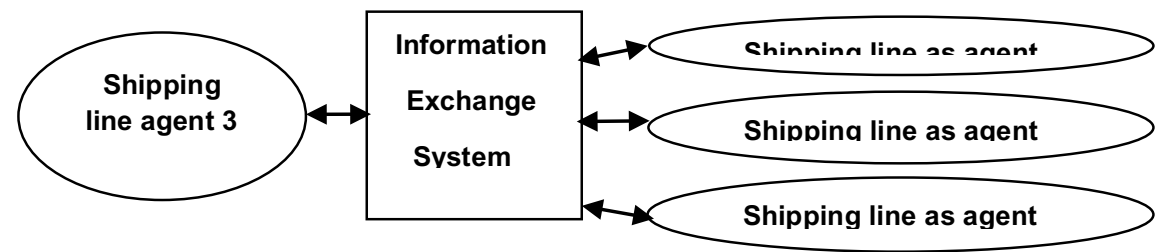

Fig. 3. MAS model for secondary market.

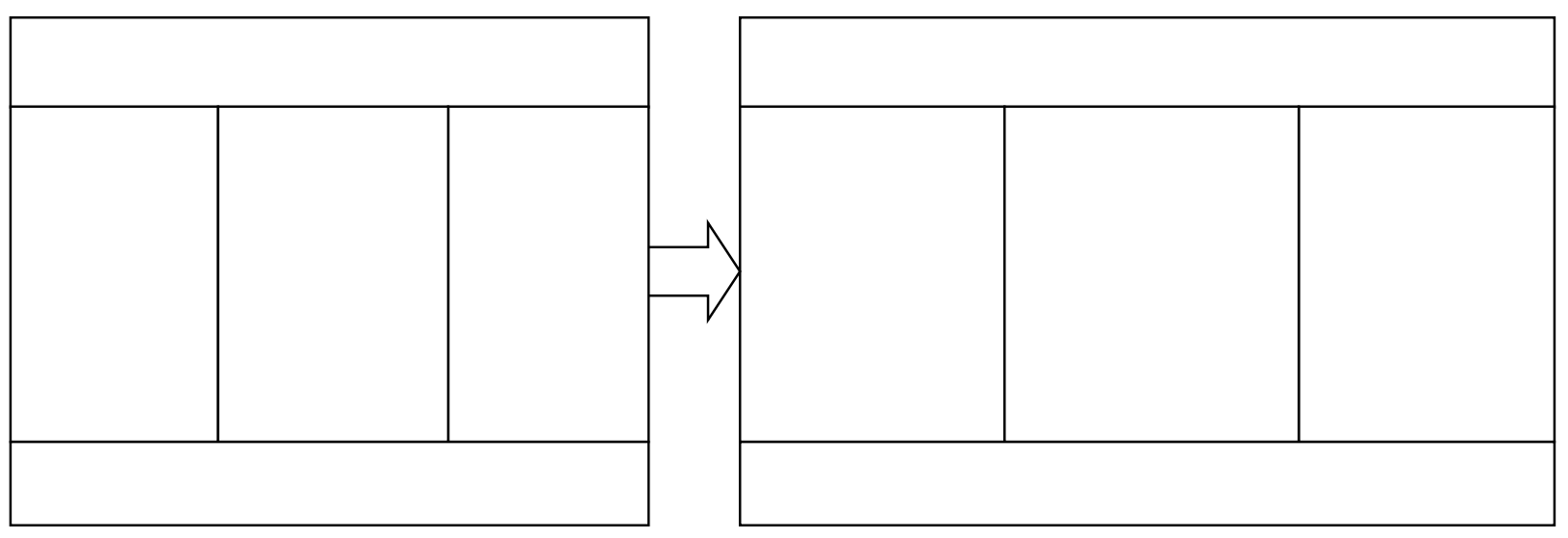

Fig. 4. Overall MAS structure to liner shipping logistics system. 


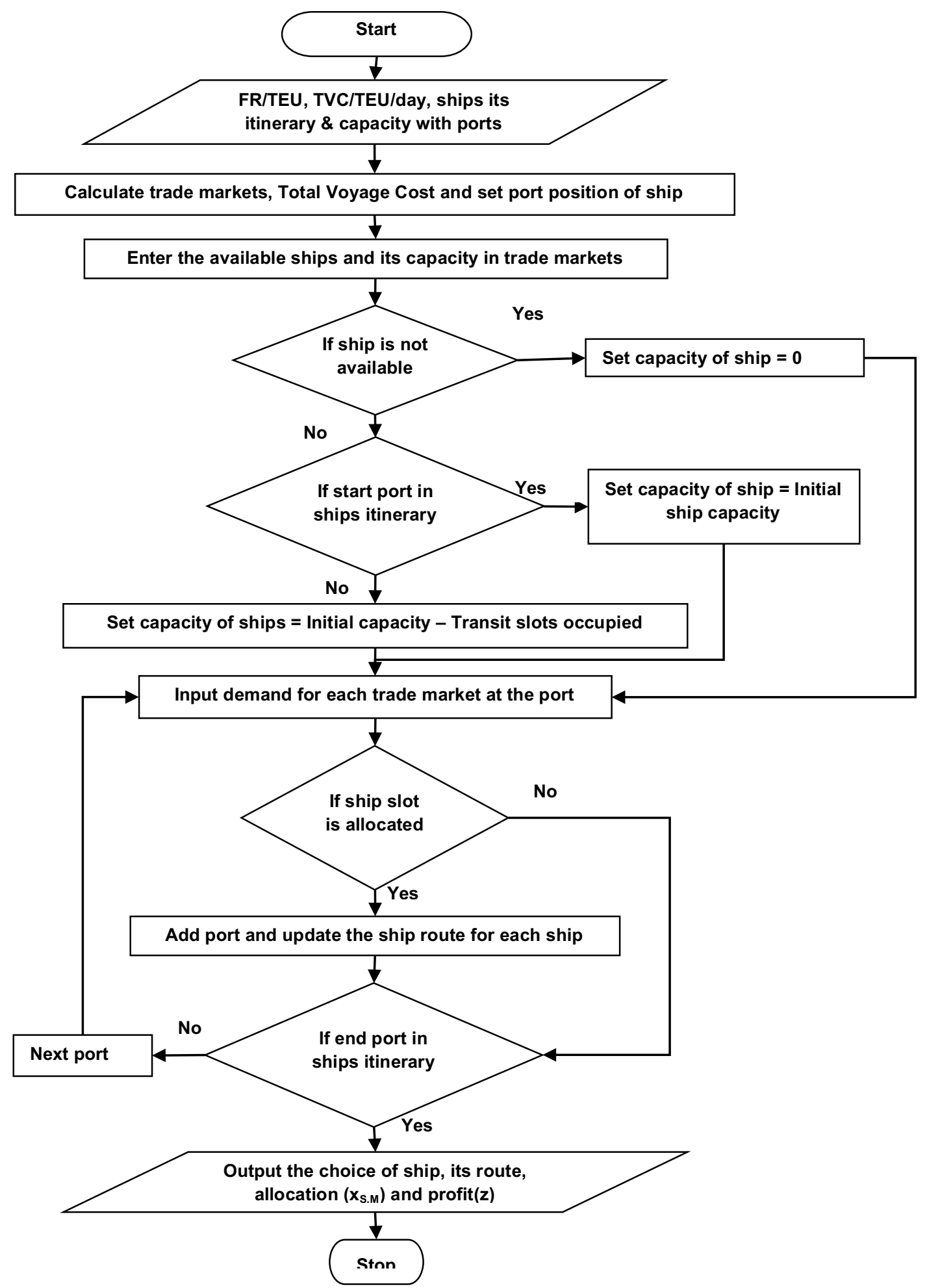

Fig. 5. Flowchart for method 1 - AIMMS software. 


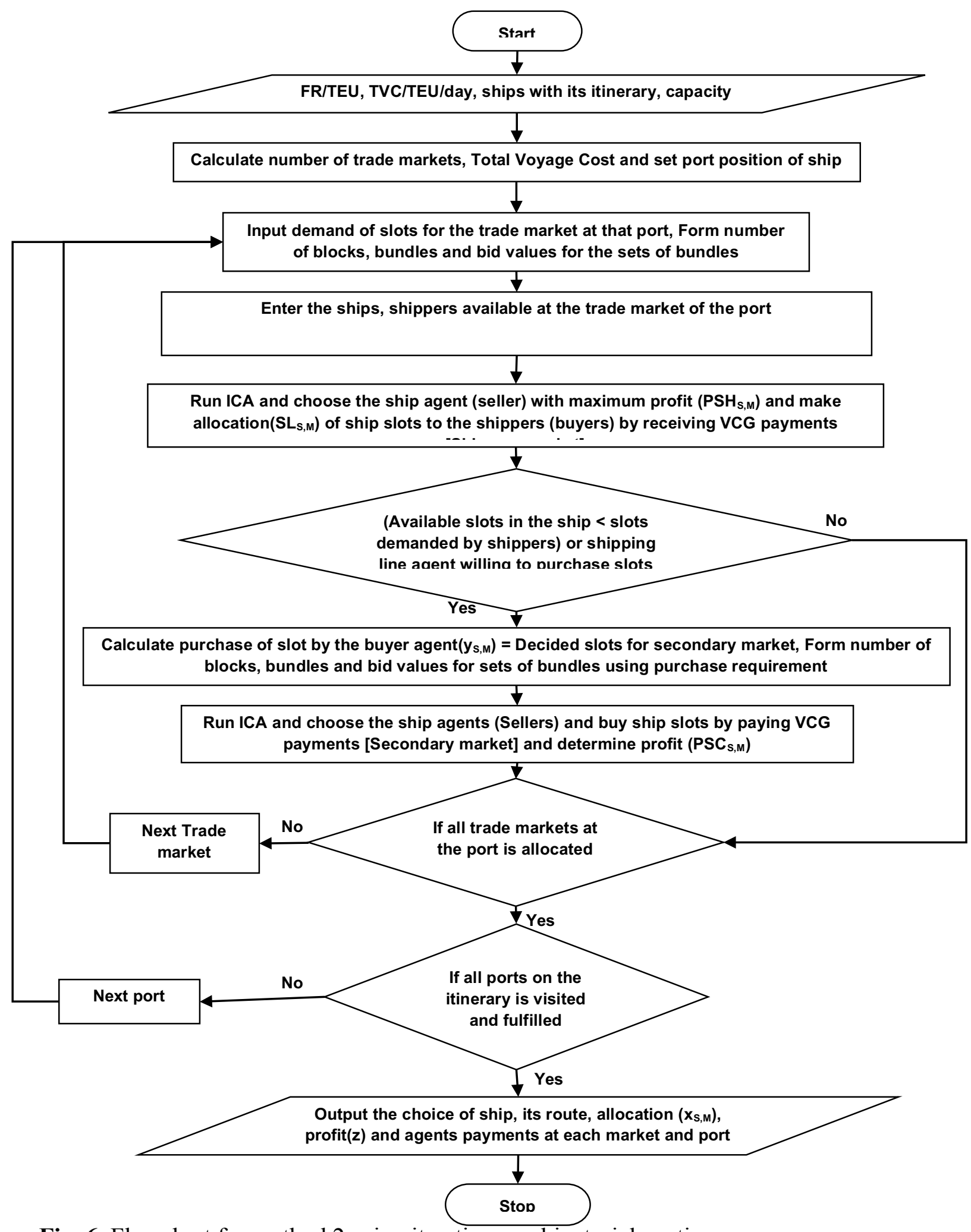

Fig. 6. Flowchart for method 2 using iterative combinatorial auction. 


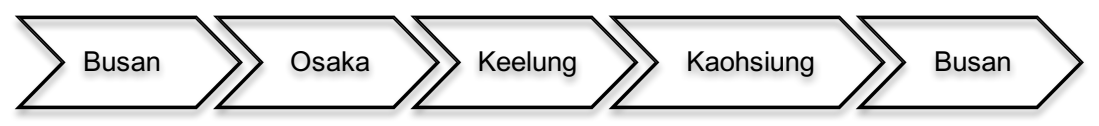

Fig. 7. The cyclic ship route considered for illustration.

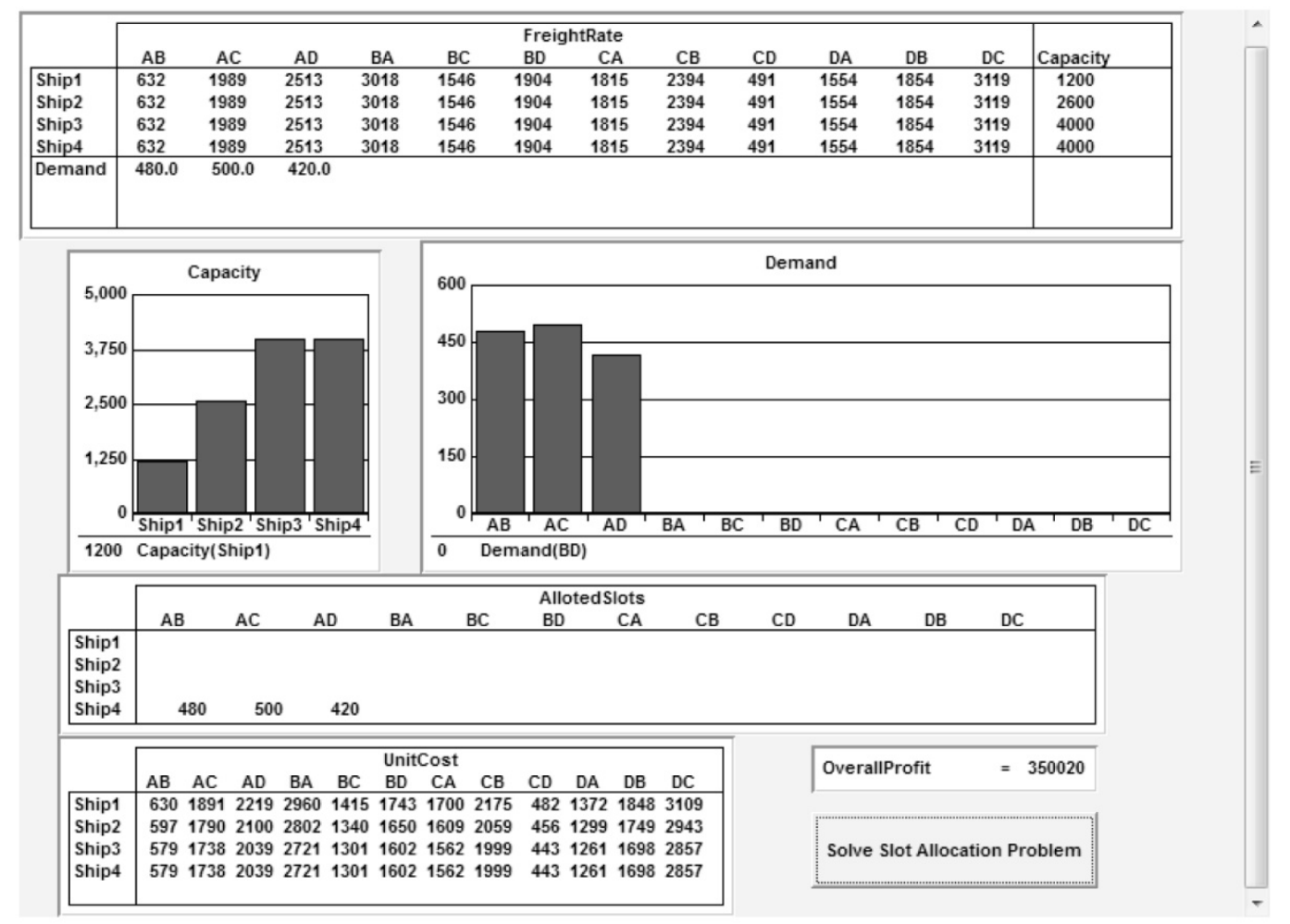

Fig. 8. AIMMS output for ship position at Busan. 


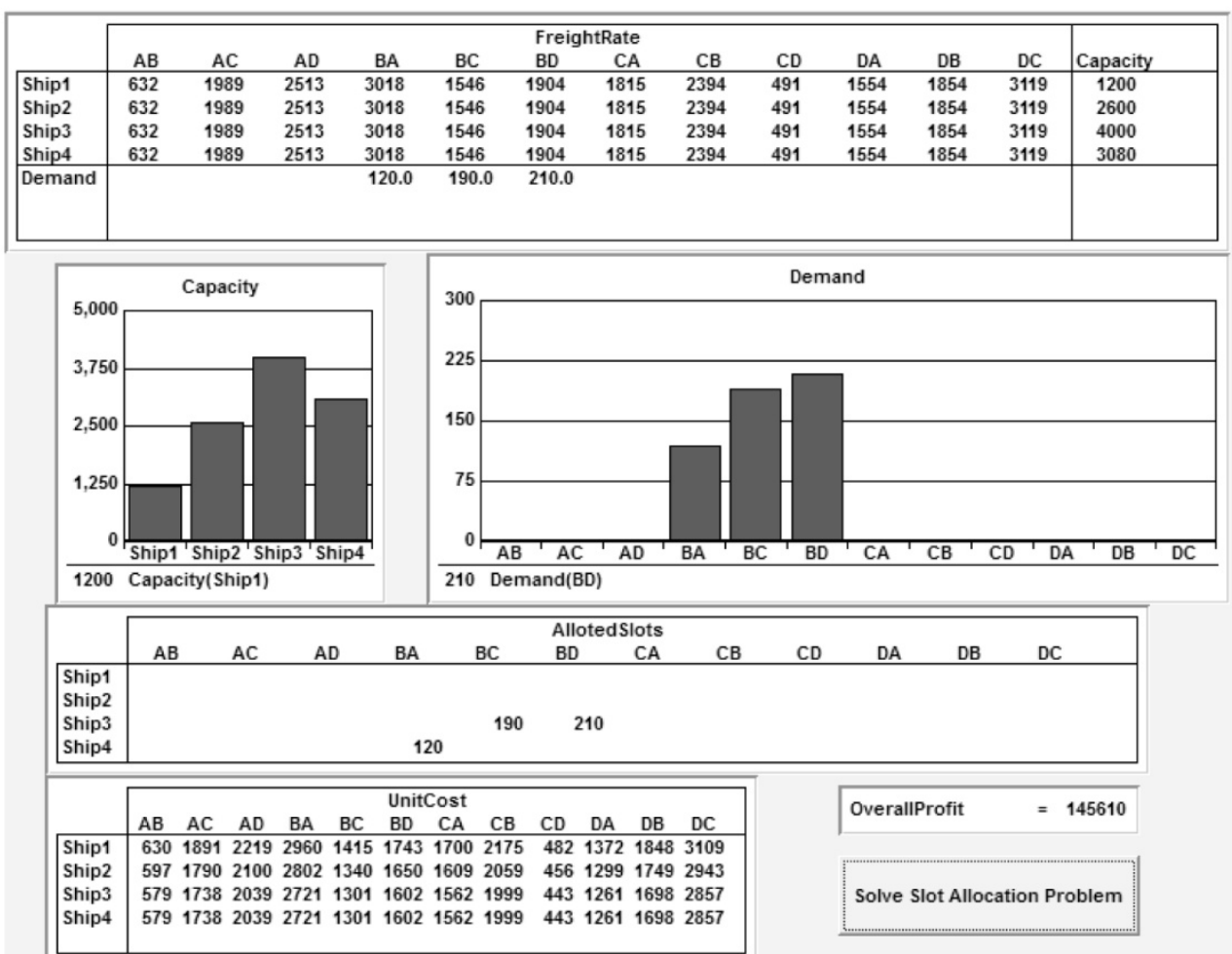

Fig. 9. AIMMS output for ship position at Osaka. 


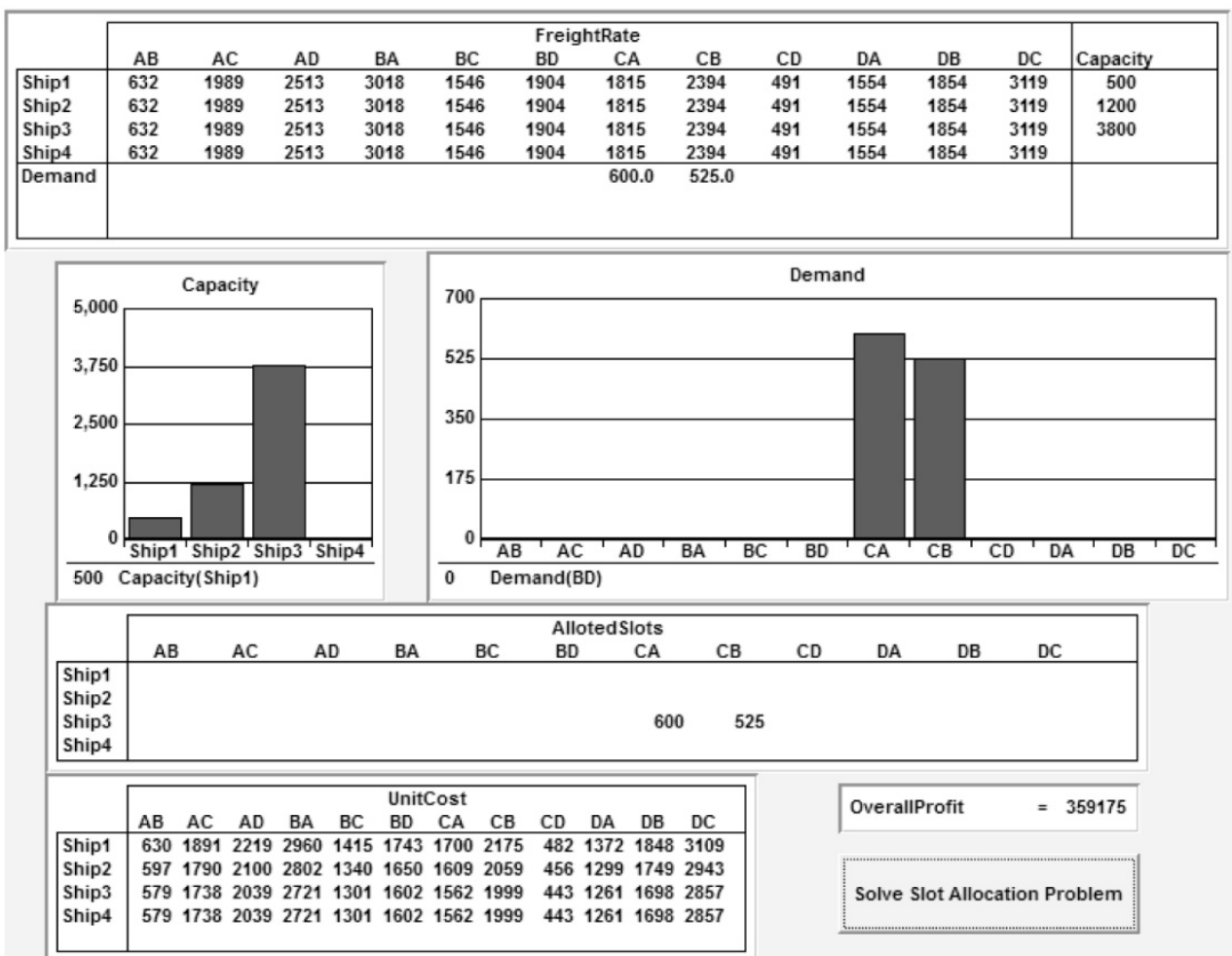

Fig. 10. AIMMS output for ship position at Keelung. 


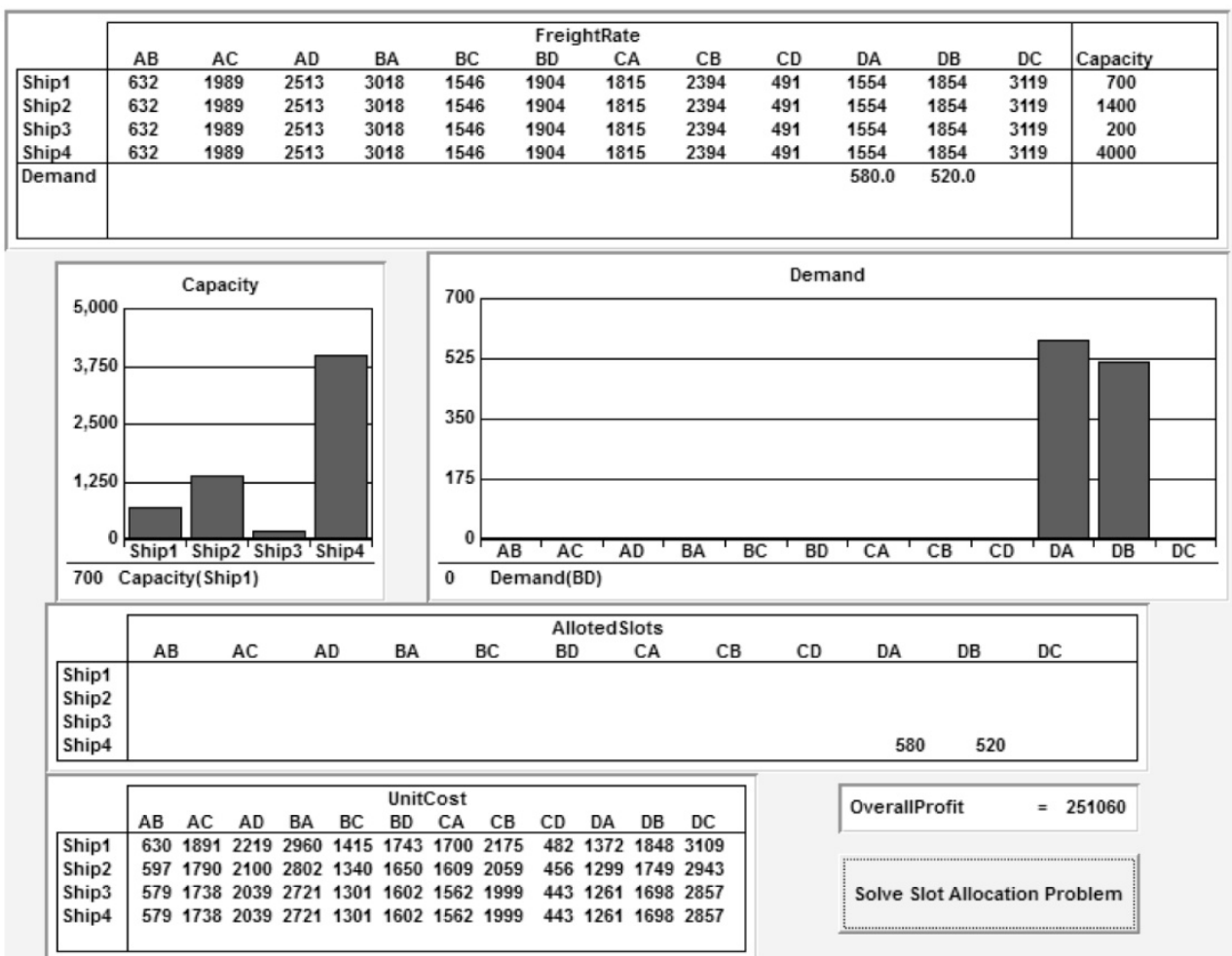

Fig. 11. AIMMS output for ship position at Kaohsiung. 


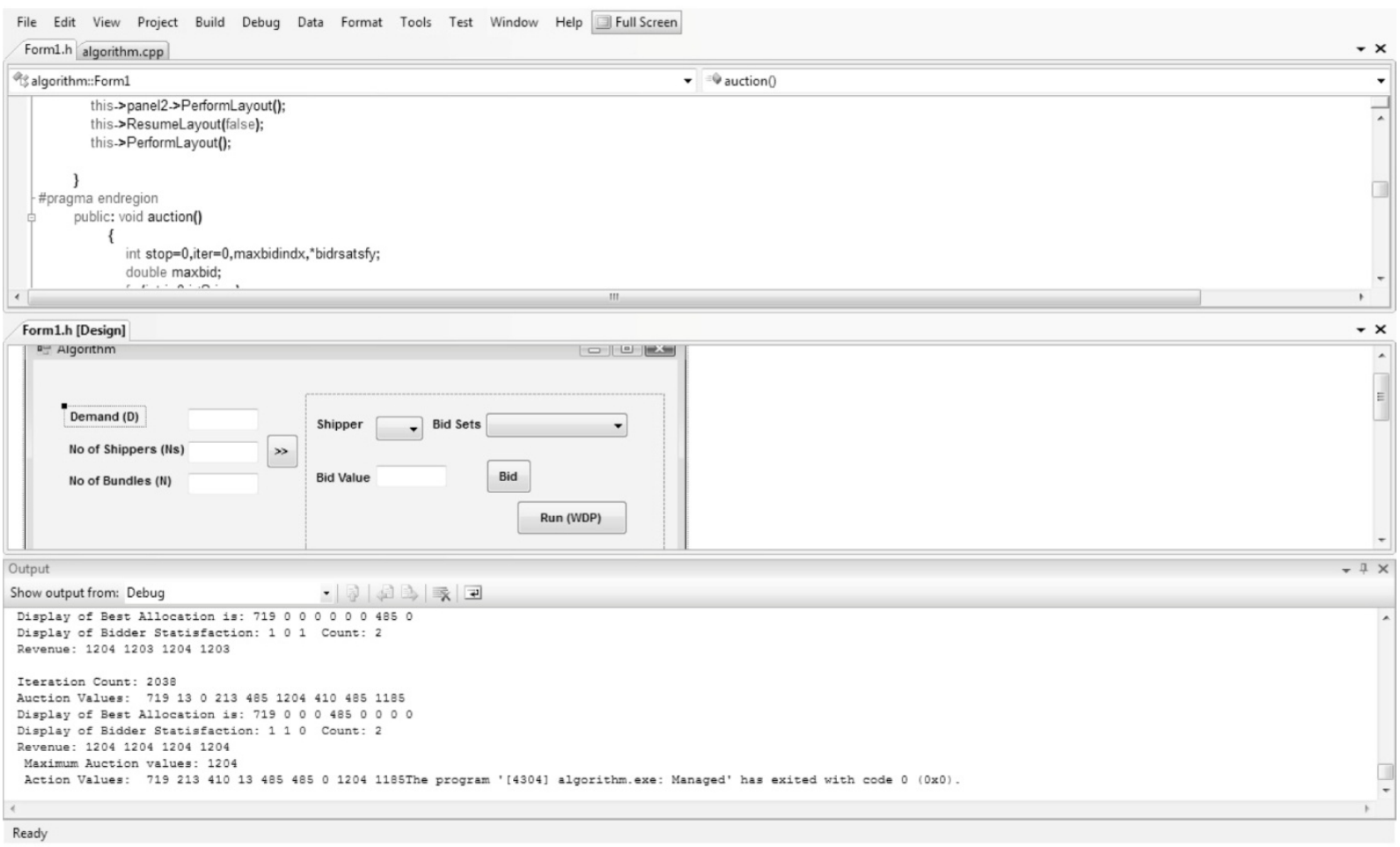

Fig. 12. The screen shot of the $\mathrm{V} \mathrm{C}++$ software output obtained using ICA. 
Table 1: Input data for illustration

\begin{tabular}{|c|c|c|c|c|c|c|c|c|c|c|c|c|c|}
\hline \multirow{2}{*}{\multicolumn{2}{|c|}{$\begin{array}{l}\text { Name of Ports } \\
\text { Minimum Draft in } m\end{array}$}} & \multicolumn{3}{|c|}{ Busan $-A$} & \multicolumn{3}{|c|}{ Osaka-B } & \multicolumn{3}{|c|}{ KeeLung - C } & \multicolumn{3}{|c|}{ Kaohsiung -D } \\
\hline & & & 12.45 & & & 12 & & & 15.5 & & & 15 & \\
\hline \multicolumn{2}{|c|}{ Markets (Loaded(o) - unloaded(d)) } & A-B & $\mathrm{A}-\mathrm{C}$ & A-D & B-A & $\mathrm{B}-\mathrm{C}$ & B-D & $\mathrm{C}-\mathrm{A}$ & C-B & C-D & D-A & D-B & $\mathrm{D}-\mathrm{C}$ \\
\hline \multirow{2}{*}{ Distance $(1 \mathrm{~nm}=1.852 \mathrm{~km})$} & $\mathrm{Nm}$ & 352 & 1283 & 1525 & 2073 & 931 & 1173 & 1142 & 1494 & 242 & 900 & 1252 & 2183 \\
\hline & $\mathrm{Km}$ & 652 & 2376 & 2824 & 3839 & 1724 & 2172 & 2115 & 2767 & 448 & 1667 & 2319 & 4043 \\
\hline \multicolumn{2}{|l|}{ Days of travel at 19 knots } & 0.77 & 2.81 & 3.34 & 4.54 & 2.04 & 2.57 & 2.50 & 3.27 & 0.53 & 1.97 & 2.74 & 4.78 \\
\hline \multicolumn{2}{|l|}{ Handling time in days } & 0.25 & 0.25 & 0.25 & 0.25 & 0.25 & 0.25 & 0.25 & 0.25 & 0.25 & 0.25 & 0.25 & 0.25 \\
\hline \multicolumn{2}{|l|}{ Total Voyage time( $\mathrm{T})$ in days } & 1.02 & 3.06 & 3.59 & 4.79 & 2.29 & 2.82 & 2.75 & 3.52 & 0.78 & 2.22 & 2.99 & 5.03 \\
\hline & Ship1 - 1200 TEU & 630 & 1891 & 2219 & 2960 & 1415 & 1743 & 1700 & 2175 & 482 & 1372 & 1848 & 3109 \\
\hline $\mathrm{TVC} / \mathrm{TEU} /$ day $* \mathrm{~T}$ in & Ship2 - 2500 TEU & 597 & 1790 & 2100 & 2802 & 1340 & 1650 & 1609 & 2059 & 456 & 1299 & 1749 & 2943 \\
\hline \multirow[t]{2}{*}{ dollars } & Ship3 - 4000 TEU & 579 & 1738 & 2039 & 2721 & 1301 & 1602 & 1562 & 1999 & 443 & 1261 & 1698 & 2857 \\
\hline & Ship4 - 4000 TEU & 579 & 1738 & 2039 & 2721 & 1301 & 1602 & 1562 & 1999 & 443 & 1261 & 1698 & 2857 \\
\hline \multicolumn{2}{|l|}{ Freight Rate/TEUin dollars } & 470 & 500 & 550 & 340 & 420 & 440 & 700 & 680 & 0 & 700 & 620 & 0 \\
\hline \multicolumn{2}{|c|}{ Demand of ship slots at each leg $\left(D_{M}\right)$} & 480 & 500 & 420 & 120 & 190 & 210 & 600 & 525 & 0 & 580 & 520 & 0 \\
\hline
\end{tabular}

Source: http://www1.axsmarine.com, New Zealand Shippers’ Council, August 2010, Book of Martin Stopford (1997),Chen and Zeng (2010) 
Table 2: Procedure to bundle ship slots

\begin{tabular}{|c|c|c|c|c|c|c|c|c|c|c|c|c|}
\hline \multirow{2}{*}{ Description } & \multicolumn{12}{|c|}{ Trade markets } \\
\hline & $A-B$ & $A-C$ & $A-D$ & $B-A$ & $B-C$ & $B-D$ & $C-A$ & $C-B$ & $C-D$ & $D-A$ & $D-B$ & $D-C$ \\
\hline Demand of slots & 480 & 500 & 420 & 120 & 190 & 210 & 600 & 525 & - & 580 & 520 & - \\
\hline Number of blocks (n) $\left[1\right.$ block $\left.=D_{M} / n\right]$ & 10 & 10 & 10 & 10 & 10 & 10 & 10 & 10 & 10 & 10 & 10 & 10 \\
\hline Number of bundles (m) & 2 & 2 & 2 & 2 & 2 & 2 & 2 & 2 & 2 & 2 & 2 & 2 \\
\hline Bundle size (n/m) & 5 & 5 & 5 & 5 & 5 & 5 & 5 & 5 & 5 & 5 & 5 & 5 \\
\hline Number of bundle sets $\left(2^{\mathrm{m}}\right)$ & 4 & 4 & 4 & 4 & 4 & 4 & 4 & 4 & 4 & 4 & 4 & 4 \\
\hline Set $\{0\}$ in TEU & - & - & - & - & - & - & - & - & - & - & - & - \\
\hline Set $\{1\}$ in TEU & 240 & 250 & 210 & 60 & 95 & 105 & 300 & 262 & - & 290 & 260 & - \\
\hline Set $\{2\}$ in TEU & 240 & 250 & 210 & 60 & 95 & 105 & 300 & 263 & - & 290 & 260 & - \\
\hline Set $\{1,2\}$ in TEU & 480 & 500 & 420 & 120 & 190 & 210 & 600 & 525 & - & 580 & 520 & - \\
\hline
\end{tabular}


Table 3: Bid values for bundles in each market.

\begin{tabular}{|c|c|c|c|c|c|c|c|c|c|c|c|c|c|c|}
\hline \multirow{2}{*}{ Ships } & \multirow{2}{*}{ Shippers } & \multirow{2}{*}{ Bundles } & \multicolumn{12}{|c|}{ Bid values in US dollars for bundles in each market } \\
\hline & & & $A-B$ & $A-C$ & $A-D$ & $B-A$ & $B-C$ & $B-D$ & $C-A$ & $C-B$ & $C-D$ & $D-A$ & $D-B$ & $D-C$ \\
\hline \multirow{9}{*}{$\neg$} & \multirow{3}{*}{$m$} & $\{1\}$ & 475 & 500 & 550 & 350 & 425 & 450 & 700 & 675 & - & 700 & 625 & - \\
\hline & & $\{2\}$ & 525 & 550 & 625 & 425 & 525 & 500 & 775 & 700 & - & 800 & 750 & - \\
\hline & & $\{1,2\}$ & 800 & 850 & 975 & 675 & 750 & 775 & 1200 & 980 & - & 1250 & 1050 & - \\
\hline & \multirow{4}{*}{$N$} & $\{1\}$ & 492 & 525 & 601 & 395 & 501 & 499 & 746 & 683 & - & 764 & 671 & - \\
\hline & & $\{2\}$ & 599 & 673 & 831 & 504 & 714 & 619 & 1031 & 744 & - & 1055 & 851 & - \\
\hline & & $\{1,2\}$ & 1037 & 854 & 1185 & 1081 & 873 & 886 & 1249 & 1182 & - & 1250 & 1179 & - \\
\hline & & $\{1\}$ & 596 & 577 & 778 & 414 & 692 & 571 & 793 & 732 & - & 995 & 760 & - \\
\hline & \multirow[t]{3}{*}{-} & $\{2\}$ & 702 & 763 & 1126 & 706 & 721 & 764 & 1148 & 993 & - & 1222 & 923 & - \\
\hline & & $\{1,2\}$ & 1090 & 1185 & 1203 & 1221 & 1143 & 1144 & 1250 & 1244 & - & 1250 & 1183 & - \\
\hline \multirow{9}{*}{$\sim$} & & $\{1\}$ & 475 & 500 & 550 & 350 & 425 & 450 & 700 & 675 & - & 700 & 625 & - \\
\hline & \multirow[t]{2}{*}{$m$} & $\{2\}$ & 525 & 550 & 625 & 425 & 525 & 500 & 775 & 700 & - & 800 & 750 & - \\
\hline & & $\{1,2\}$ & 800 & 850 & 975 & 675 & 750 & 775 & 1200 & 980 & - & 1250 & 1050 & - \\
\hline & \multirow{4}{*}{$N$} & $\{1\}$ & 480 & 535 & 597 & 418 & 457 & 464 & 771 & 681 & - & 728 & 714 & - \\
\hline & & $\{2\}$ & 734 & 594 & 929 & 611 & 615 & 580 & 822 & 850 & - & 1118 & 1015 & - \\
\hline & & $\{1,2\}$ & 1210 & 1099 & 1205 & 1189 & 868 & 801 & 1217 & 1183 & - & 1250 & 1107 & - \\
\hline & & $\{1\}$ & 567 & 539 & 917 & 512 & 490 & 538 & 807 & 775 & - & 1018 & 945 & - \\
\hline & \multirow[t]{3}{*}{-} & $\{2\}$ & 1120 & 1098 & 1061 & 756 & 689 & 658 & 1174 & 1036 & - & 1129 & 1081 & - \\
\hline & & $\{1,2\}$ & 1236 & 1112 & 1236 & 1203 & 1050 & 999 & 1235 & 1201 & - & 1250 & 1244 & - \\
\hline \multirow{9}{*}{$m$} & & $\{1\}$ & 475 & 500 & 550 & 350 & 425 & 450 & 700 & 675 & - & 700 & 625 & - \\
\hline & \multirow[t]{2}{*}{$m$} & $\{2\}$ & 525 & 550 & 625 & 425 & 525 & 500 & 775 & 700 & - & 800 & 750 & - \\
\hline & & $\{1,2\}$ & 800 & 850 & 975 & 675 & 750 & 775 & 1200 & 980 & - & 1250 & 1050 & - \\
\hline & \multirow{4}{*}{$N$} & $\{1\}$ & 685 & 769 & 975 & 365 & 582 & 541 & 1085 & 847 & - & 1236 & 941 & - \\
\hline & & $\{2\}$ & 636 & 637 & 887 & 543 & 745 & 545 & 1110 & 794 & - & 1130 & 876 & - \\
\hline & & $\{1,2\}$ & 1026 & 1166 & 1199 & 1125 & 1037 & 1005 & 1164 & 1197 & - & 928 & 821 & - \\
\hline & & $\{1\}$ & 525 & 525 & 550 & 397 & 471 & 467 & 762 & 681 & - & 769 & 660 & - \\
\hline & \multirow[t]{3}{*}{-} & $\{2\}$ & 770 & 596 & 962 & 639 & 722 & 772 & 882 & 928 & - & 1015 & 976 & - \\
\hline & & $\{1,2\}$ & 950 & 873 & 1194 & 945 & 972 & 837 & 1218 & 1178 & - & 1058 & 946 & - \\
\hline \multirow{9}{*}{$\nabla$} & & $\{1\}$ & 475 & 500 & 550 & 350 & 425 & 450 & 700 & 675 & - & 700 & 625 & - \\
\hline & \multirow[t]{2}{*}{$m$} & $\{2\}$ & 525 & 550 & 625 & 425 & 525 & 500 & 775 & 700 & - & 800 & 750 & - \\
\hline & & $\{1,2\}$ & 800 & 850 & 975 & 675 & 750 & 775 & 1200 & 980 & - & 1250 & 1050 & - \\
\hline & \multirow{4}{*}{$N$} & $\{1\}$ & 517 & 519 & 616 & 399 & 428 & 474 & 719 & 696 & - & 710 & 692 & - \\
\hline & & $\{2\}$ & 624 & 735 & 900 & 534 & 556 & 694 & 991 & 854 & - & 980 & 1039 & - \\
\hline & & $\{1,2\}$ & 1103 & 1087 & 1169 & 1010 & 1219 & 793 & 1204 & 1009 & - & 1250 & 1196 & - \\
\hline & & $\{1\}$ & 515 & 544 & 606 & 371 & 514 & 461 & 707 & 695 & - & 761 & 654 & - \\
\hline & \multirow[t]{2}{*}{-} & $\{2\}$ & 771 & 579 & 688 & 668 & 597 & 575 & 910 & 800 & - & 904 & 952 & - \\
\hline & & $\{1,2\}$ & 1068 & 1248 & 919 & 939 & 1109 & 886 & 888 & 990 & - & 1145 & 887 & - \\
\hline
\end{tabular}


Table 4: Ship's profit $\left(\mathrm{PSH}_{\mathrm{S}, \mathrm{M}}\right)$, Shippers payment and slot allocation $\left(\mathrm{SL}_{\mathrm{S}, \mathrm{M}}\right)$ at primary market C-A

\begin{tabular}{|c|c|c|c|c|c|c|c|c|c|c|c|c|}
\hline Ships & \multicolumn{3}{|c|}{ Shipl } & \multicolumn{3}{|c|}{ Ship2 } & \multicolumn{3}{|c|}{ Ship3 } & \multicolumn{3}{|c|}{ Ship4 } \\
\hline \multirow[t]{2}{*}{ Ship Profit in US dollars } & \multicolumn{3}{|c|}{960300.00} & \multicolumn{3}{|c|}{1014750.00} & \multicolumn{3}{|c|}{983400.00} & \multicolumn{3}{|c|}{1049400.00} \\
\hline & 1 & 2 & 3 & 1 & 2 & 3 & 1 & 2 & 3 & 1 & 2 & 3 \\
\hline Slot Allocation to shippers & - & - & 600 & - & - & 600 & 600 & - & - & 300 & 300 & \\
\hline VCG Payment by shippers in dollars & - & - & 1200 & - & - & 1200 & 1164 & - & - & 719 & 485 & - \\
\hline
\end{tabular}


Table 5: Slot allocation ( $\left.\mathrm{y}_{\mathrm{S}, \mathrm{M}}\right)$ and profit $(\mathrm{z})$ in secondary market C-A

\begin{tabular}{lccc}
\hline Purchaser of slots $\left(y_{S, M}\right)$ is Ship 4, Ship 4 allocation $=600$, Ship 4 Profit $\left(\right.$ PSH $\left._{S, \mathrm{M}}\right)=\mathbf{1 0 4 9 4 0 0 . 0 0}$ in dollars \\
\hline Sellers of slots & Ship 1 & Ship 2 & Ship 3 \\
Slots sold by sellers $\left(\mathrm{y}_{\mathrm{S}, \mathrm{M}}\right)$ & - & - & 600 \\
Exchange price $\left(\mathrm{EP}_{\mathrm{S}, \mathrm{M}}\right)$ in US dollars & - & - & 650 \\
VCG payment for Seller Shipping line in US dollars & - & - & 650 \\
Profit earned by seller shipping line (z) in dollars & - & - & 135300 \\
Profit earned by buyer shipping line(z) in dollars & - & - & 914100 \\
\hline
\end{tabular}


Table 6: Ship profit $(\mathrm{z})$ and slot allocation ( $\mathrm{x}_{\mathrm{S}, \mathrm{M}}$ ) using CPLEX 12.5 in AIMMS

\begin{tabular}{|c|c|c|c|c|c|c|c|c|}
\hline \multirow[t]{2}{*}{ Trade markets } & \multicolumn{4}{|c|}{$\operatorname{Allocation}\left(x_{S, M}\right)$} & \multicolumn{4}{|c|}{ Profit(z) in dollars } \\
\hline & Ship 1 & Ship 2 & Ship 3 & Ship 4 & Shipl & Ship 2 & Ship 3 & Ship 4 \\
\hline A-B & - & - & - & 480 & - & - & - & 25440 \\
\hline A-C & - & - & - & 500 & - & - & - & 125500 \\
\hline A-D & - & - & - & 420 & - & - & - & 199080 \\
\hline B-A & - & - & - & 120 & - & - & - & 35640 \\
\hline B-C & - & - & - & 190 & - & - & - & 46550 \\
\hline B-D & - & - & - & 210 & - & - & - & 63420 \\
\hline C-A & - & - & - & 600 & - & - & - & 151800 \\
\hline C-B & - & - & - & 525 & - & - & - & 207375 \\
\hline C-D & & & & - & & & & 0 \\
\hline D-A & - & - & - & 580 & - & - & - & 169940 \\
\hline D-B & - & - & - & 520 & - & - & - & 81120 \\
\hline \multirow[t]{2}{*}{ D-C } & - & - & - & - & - & - & - & 0 \\
\hline & & & \multicolumn{2}{|c|}{ Overall Profit } & - & - & - & 1105865 \\
\hline
\end{tabular}


Table 7: Ship selected with its route using CPLEX 12.5 in AIMMS

\begin{tabular}{lllll}
\hline Ships & Ship1 & Ship2 & Ship3 & Ship4 \\
\hline Route & - & - & - & A-B-C-D-A \\
\hline
\end{tabular}


Table 8: Ship profit $\left(\mathrm{PSH}_{\mathrm{S}, \mathrm{M}}\right)$ and Slot allocation $\left(\mathrm{SL}_{\mathrm{S}, \mathrm{M}}\right)$ in primary market

\begin{tabular}{|c|c|c|c|c|c|c|c|c|c|c|c|c|}
\hline \multirow{3}{*}{$\begin{array}{c}\begin{array}{c}\text { Trade } \\
\text { Markets }\end{array} \\
\text { A-B }\end{array}$} & \multirow{3}{*}{$\begin{array}{c}\text { Shippers } \\
1\end{array}$} & \multicolumn{8}{|c|}{ Allocation and Payment Received by ship from shippers } & \multirow{3}{*}{$\begin{array}{c}\text { Ship } \\
\text { Chosen with } \\
\text { Max.Profit }\end{array}$} & \multirow{3}{*}{$\begin{array}{c}\text { Allocation } \\
\left(S L_{S, M}\right)\end{array}$} & \multirow{3}{*}{$\begin{array}{l}\text { Profit }\left(P_{S H} H_{S, M}\right) \\
\quad \text { in dollars }\end{array}$} \\
\hline & & \multicolumn{2}{|c|}{ Ship1 } & \multicolumn{2}{|c|}{ Ship2 } & \multicolumn{2}{|c|}{ Ship3 } & \multicolumn{2}{|c|}{ Ship4 } & & & \\
\hline & & - & - & - & - & - & - & - & - & & & \\
\hline & 2 & - & - & - & - & 480 & 800 & 480 & 800 & Shin 3 & 480 & 113587.20 \\
\hline & 3 & 480 & 800 & 480 & 800 & - & - & - & - & Ship3 & 480 & \\
\hline \multicolumn{2}{|c|}{ Ship's profit } & \multicolumn{2}{|c|}{89107.20} & \multicolumn{2}{|c|}{105264.00} & \multicolumn{2}{|c|}{113587.20} & \multicolumn{2}{|c|}{113587.20} & & & \\
\hline \multirow[t]{3}{*}{ A-C } & 1 & - & - & - & - & - & - & - & - & & & \\
\hline & 2 & - & - & - & - & - & - & 500 & 850 & & & 431460.00 \\
\hline & 3 & 500 & 850 & 500 & 850 & 500 & 850 & - & - & Ship3 & 500 & \\
\hline \multicolumn{2}{|c|}{ Ship's profit } & \multicolumn{2}{|c|}{354960.00} & 405 & 0.00 & 431 & 0.00 & 431 & 0.00 & & & \\
\hline A-D & 1 & - & - & - & - & - & - & - & - & & & \\
\hline & 2 & 420 & 850 & 420 & 975 & - & - & - & - & Shin & 420 & 613674.60 \\
\hline & 3 & - & - & - & - & 420 & 975 & 420 & 920 & Snip3 & 420 & \\
\hline & profit & 538 & 4.60 & & & 613 & 4.60 & 530 & 5.60 & & & \\
\hline B-A & 1 & - & - & - & - & - & - & - & - & & & \\
\hline & 2 & 120 & 675 & 120 & 675 & 120 & 675 & - & - & & & 61503.60 \\
\hline & 3 & - & - & - & - & - & - & 120 & 675 & Ship3 & 120 & \\
\hline & profit & 327 & 3.60 & & & 615 & .60 & & 3.60 & & & \\
\hline B-C & 1 & - & - & - & - & - & - & - & - & & & \\
\hline & 2 & - & - & - & - & - & - & - & - & & & 79188.20 \\
\hline & 3 & 190 & 750 & 190 & 750 & 190 & 750 & 190 & 750 & Ship3 & 190 & \\
\hline & profit & 574 & 3.20 & 717 & 1.50 & 791 & 3.20 & & 8.20 & & & \\
\hline B-D & 1 & - & - & - & - & - & - & - & - & & & \\
\hline & 2 & 210 & 775 & 210 & 775 & - & - & - & - & Ship3 & 210 & 122585.40 \\
\hline & 3 & - & - & - & - & 210 & 775 & 210 & 775 & SnıрJ & 210 & \\
\hline & profit & 929 & 5.40 & & & 122 & 5.40 & 122 & 5.40 & & & \\
\hline C-A & 1 & - & - & - & - & 600 & 1164 & 300 & 719 & & & \\
\hline & 2 & - & - & - & - & - & - & 300 & 485 & & & 1049400.00 \\
\hline & 3 & 600 & 1200 & 600 & 1200 & - & - & - & - & Ship4 & 600 & \\
\hline & profit & 960 & 0.00 & 1014 & 50.00 & 983 & 0.00 & 104 & 00.00 & & & \\
\hline C-B & 1 & - & - & - & - & - & - & - & - & & & \\
\hline & 2 & - & - & - & - & 525 & 980 & 525 & 980 & & 525 & 761376.00 \\
\hline & 3 & 525 & 980 & 525 & 980 & - & - & - & - & Shıp3 & 525 & \\
\hline & profit & 668 & 6.00 & 729 & 0.00 & 761 & 6.00 & & 6.00 & & & \\
\hline C-D & 1 & - & - & - & - & - & - & - & - & & & \\
\hline & 2 & - & - & - & - & - & - & - & - & & & \\
\hline & 3 & - & - & - & - & & - & - & - & - & - & - \\
\hline & profit & & & & & & & & & & & \\
\hline D-A & 1 & - & - & - & - & - & - & 580 & 1145 & & & \\
\hline & 2 & - & - & - & - & 290 & 929 & - & - & & 580 & 856254.00 \\
\hline & 3 & 580 & 1250 & 580 & 1250 & 290 & 43 & - & - & Ship2 & 580 & \\
\hline Shi & profit & 813 & 3.20 & 856 & 4.00 & 795 & 6.80 & 742 & 5.20 & & & \\
\hline D-B & 1 & - & - & - & - & 260 & 525 & 260 & 692 & & & \\
\hline & 2 & - & - & - & - & 260 & 525 & & - & Shind & 52. & 853585.20 \\
\hline & 3 & 520 & 1050 & 520 & 1050 & - & - & 260 & 425 & Snıp4 & 520 & \\
\hline & profit & 671 & 3.60 & 722 & 2.00 & 749 & 3.60 & 853 & 5.20 & & & \\
\hline D-C & 1 & - & - & - & - & - & - & - & - & & & \\
\hline & 2 & - & - & - & - & - & - & - & - & & - & - \\
\hline & 3 & - & - & - & - & & & - & - & - & - & - \\
\hline Ship's p & $\mathrm{fit}\left(\mathrm{PSH}_{\mathrm{S}, \mathrm{M}}\right)$ & & & & & & & & & & & \\
\hline
\end{tabular}


Table 9: Slots $\left(\mathrm{y}_{\mathrm{S}, \mathrm{M}}\right)$ and their profit $\left(\mathrm{PSC}_{\mathrm{S}, \mathrm{M}}\right)$ after slot chartering market

\begin{tabular}{|c|c|c|c|c|c|c|c|c|c|c|}
\hline $\begin{array}{l}\text { Trade } \\
\text { markets } \\
(M)\end{array}$ & $\begin{array}{c}\text { Slots } \\
\text { bought } \\
\left(y_{S, M}\right)\end{array}$ & Buyers & $\begin{array}{l}\text { Buyer profit } \\
\left(P S C_{S, M}\right) \text { in } \\
\text { dollars }\end{array}$ & Sellers & \multicolumn{2}{|c|}{$\begin{array}{c}\text { Bid values in } \\
\text { US dollars }\end{array}$} & Allocation & $\begin{array}{c}\text { Exchange } \\
\text { price } \\
\left(E P_{S, M}\right) \text { in } \\
\text { dollars } \\
\end{array}$ & $\begin{array}{c}\text { VCG Payment } \\
\text { for seller } \\
\left(\text { VCG } G_{S . M}\right) \text { in US } \\
\text { dollars }\end{array}$ & $\begin{array}{c}\text { Seller } \\
\text { profit (z) } \\
\text { in dollars }\end{array}$ \\
\hline \multirow{10}{*}{ C-A } & \multirow{10}{*}{600} & \multirow{10}{*}{ Ship4 } & \multirow{10}{*}{1353000} & & $\{1\}$ & 570 & & & - & \\
\hline & & & & Ship1 & $\{2\}$ & 570 & - & - & & - \\
\hline & & & & & $\{1,2\}$ & 690 & & & & \\
\hline & & & & & $\{1\}$ & 0 & & & - & \\
\hline & & & & Ship2 & $\{2\}$ & 0 & - & - & & - \\
\hline & & & & & $\{1,2\}$ & 650 & & & & \\
\hline & & & & & $\{1\}$ & 0 & & & 650 & \\
\hline & & & & Ship3 & $\{2\}$ & 0 & 600 & 650 & & 135300 \\
\hline & & & & & $\{1,2\}$ & 680 & & & & \\
\hline & & & & & $\{1\}$ & 0 & & & - & \\
\hline \multirow{6}{*}{ D-A } & \multirow{6}{*}{580} & \multirow{6}{*}{ Ship2 } & \multirow{6}{*}{109446} & Ship1 & $\begin{array}{l}\{2\} \\
\{1,2\}\end{array}$ & $\begin{array}{l}0 \\
680\end{array}$ & - & - & & \\
\hline & & & & & $\{1\}$ & 585 & & & 670 & \\
\hline & & & & Ship3 & $\{2\}$ & $\begin{array}{l}605 \\
670\end{array}$ & 580 & 670 & & 109446 \\
\hline & & & & & $\{1,2\}$ & $\begin{array}{l}670 \\
0\end{array}$ & & & - & \\
\hline & & & & Ship4 & $\{2\}$ & 0 & - & - & & \\
\hline & & & & & $\{1,2\}$ & 685 & & & & \\
\hline \multirow{9}{*}{ D-B } & \multirow{9}{*}{520} & \multirow{9}{*}{ Ship4 } & \multirow{9}{*}{213148} & & $\{1\}$ & 570 & & & - & \\
\hline & & & & Ship1 & $\{2\}$ & 570 & - & - & & \\
\hline & & & & & $\{1,2\}$ & 670 & & & & \\
\hline & & & & & $\{1\}$ & 0 & & & - & \\
\hline & & & & Ship2 & $\{2\}$ & 0 & - & - & & \\
\hline & & & & & $\{1,2\}$ & 650 & & & & \\
\hline & & & & & $\{1\}$ & 0 & & & 650 & \\
\hline & & & & Ship3 & $\{2\}$ & 0 & 520 & 650 & & 213148 \\
\hline & & & & & $\{1,2\}$ & 660 & & & & \\
\hline
\end{tabular}


Table 10: Profit earned by the ship agents (z) using ICA

\begin{tabular}{|c|c|c|c|c|c|c|c|c|}
\hline \multirow{2}{*}{ Trade markets } & \multicolumn{4}{|c|}{$\overline{\text { Allocation }\left(x_{S, M}\right)}$} & \multicolumn{4}{|c|}{ Profit(z)in US dollars } \\
\hline & Shipl & Ship2 & Ship3 & Ship4 & Shipl & Ship2 & Ship3 & Ship4 \\
\hline A-B & - & - & 480 & - & - & - & 113587.20 & - \\
\hline $\mathrm{A}-\mathrm{C}$ & - & - & 500 & - & - & - & 431460.00 & - \\
\hline A-D & - & - & 420 & - & - & - & 613674.60 & - \\
\hline B-A & - & - & 120 & - & - & - & 61503.60 & - \\
\hline B-C & - & - & 190 & - & - & - & 79188.20 & - \\
\hline B-D & - & - & 210 & - & - & - & 122585.40 & - \\
\hline C-A & - & - & 600 & - & - & - & 914100 & 135300 \\
\hline C-B & - & - & 525 & - & - & - & 761376.00 & - \\
\hline C-D & - & - & - & - & - & - & - & - \\
\hline D-A & - & - & 580 & - & - & 109446 & 746808 & - \\
\hline D-B & - & - & 520 & - & - & - & 640437 & 213148 \\
\hline D-C & - & - & - & - & - & - & - & - \\
\hline \multicolumn{5}{|c|}{ Overall Profit(Z) } & - & 109446 & 4484720.00 & 348448 \\
\hline
\end{tabular}


Table 11: Ship selection with its route using ICA

\begin{tabular}{lllll}
\hline Ships & Ship1 & Ship2 & Ship3 & Ship4 \\
\hline Route & - & - & A-B-C-D-A & - \\
& & & & \\
\hline
\end{tabular}

